Article

\title{
Selected Compounds Structurally Related to Acyclic Sesquiterpenoids and Their Antibacterial and Cytotoxic Activity
}

\author{
Radosław Bonikowski ${ }^{1, *}$, Paulina Świtakowska ${ }^{1}$, Monika Sienkiewicz ${ }^{2}$ and \\ Małgorzata Zakłos-Szyda ${ }^{3}$
}

1 Institute of General Food Chemistry, Łódź University of Technology, Stefanowskiego St. 4/10, 90-924 Łódź, Poland; E-Mail: paulina@toya.net.pl

2 Environmental Biology Department, Medical University of Łódź, Żeligowskiego St. 7/9, 90-752 Łódź, Poland; E-Mail: monika.sienkiewicz@umed.lodz.pl

3 Institute of Technical Biochemistry, Łódź University of Technology, Stefanowskiego St. 4/10, 90-924 Łódź, Poland; E-Mail: malgorzata.zaklos-szyda@p.lodz.pl

* Author to whom correspondence should be addressed; E-Mail: radoslaw.bonikowski@p.lodz.pl; Tel.: +48-42-631-34-20; Fax: +48-42-631-28-42.

Academic Editor: Jean Jacques Vanden Eynde

Received: 30 April 2015 / Accepted: 15 June 2015 / Published: 18 June 2015

\begin{abstract}
By implementing a common and industrially used method, 30 compounds which are structurally related to geranyl acetone, nerolidol, farnesal, farnesol and farnesyl acetate were obtained. Their antimicrobial activity against Staphylococcus aureus, Enterococcus faecalis, Enterococcus faecium, Escherichia coli, Klebsiella pneumoniae and Acinetobacter baumannii bacteria was investigated. Pharmacophore models were proposed based on the obtained results and 3D QSAR modelling. Cytotoxic effects against mainly human immortalised and normal cell lines of different origin (malignant melanoma MeWo, colorectal adenocarcinoma HT29, promyelocytic leukemia HL60, gingival fibroblasts HFIG, skin keratinocytes HaCaT and rat small intestine epithelium IEC6) were examined. The odour descriptions of newly synthesised compounds are given.
\end{abstract}

Keywords: terpenoids; geranyl acetone; nerolidol; farnesol; farnesyl acetate; structurally related compound; antimicrobial activity; cytotoxicity 


\section{Introduction}

Most of the natural acyclic sesquiterpenoids are used in the fragrance and flavour industry as odorants and flavourings. This group includes geranyl acetone (1), nerolidol (2), farnesal (3), farnesol (4) and farnesyl acetate (5) (Figure 1).

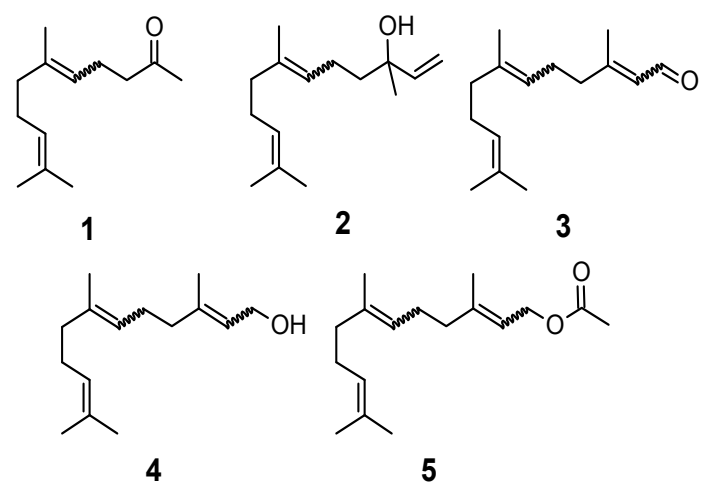

Figure 1. Structures of geranyl acetone (1); nerolidol (2); farnesal (3); farnesol (4) and farnesyl acetate (5).

Nerolidol and farnesol, in addition to their flavouring characteristics, also possess antibacterial properties. Farnesol, which is present in many creams and nourishing agents, has a bacteriostatic effect against bacteria that can cause acne (Staphylococcus aureus, Staphylococcus epidermidis) and does not affect naturally occurring microflora on the skin [1]. It blocks the formation of biofilm by the drug-resistant strains of Staphylococcus aureus and acts synergistically with antibiotics [2-4]. Brilhante et al. showed that farnesol had an inhibiting activity alone and in combination with antifungal agents against strains of dimorphic fungi from the genus Coccidioides and against Candida spp. clinical isolates [4,5]. Nerolidol shows a toxic effect against, inter alia, Salmonella enterica, Staphylococcus aureus, Escherichia coli and Aspergillus niger, and increases the antibacterial activity of antibiotics [6,7]. Nagaki et al. examined farnesal activity against $S$. aureus finding that it showed the highest activity among the analysed terpenoids [8]. Shin et al. evaluated antimicrobial activity of farnesyl acetate which inhibited the growth of $S$. aureus and Pseudomonas aeruginosa [9]. Geranyl acetone has also antimicrobial properties as shown by the examination of its food preservative ability [10]. Moreover, natural sesquiterpenoids in vivo and in vitro have chemopreventive and chemotherapeutic properties against human cancer cell lines (inter alia: human malignant melanoma, promyelocytic leukemia and lung cancer) [11-14].

In our previous studies [15-17], we described the synthesis and mainly the odour activity of the analogues of acyclic terpenoids where isobutenyl moiety was replaced by a furan or thiophene ring.

This time we decided to examine the bioactivity (scent, antibacterial and cytotoxic) of compounds structurally related to acyclic sesquiterpenoids where the osmophore and the 6-methylheptenone moiety will be maintained, and the changes will be introduced into the middle part of the chain as shown in Figure 2. 


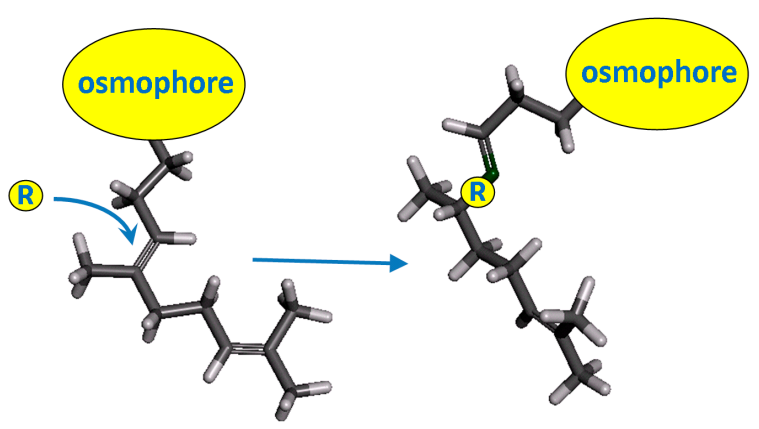

Figure 2. The structural relationship of the examined compounds to the natural sesquiterpenoids.

We reported compounds structurally related to geranyl acetone and nerolidol (Figure 3) before [18] due to their olfactory and antibacterial properties as potential fragrance components which, according to current trends, should possess added values, especially preserving properties, thus allowing for a reduction or elimination of traditional cosmetic preservatives $[19,20]$.

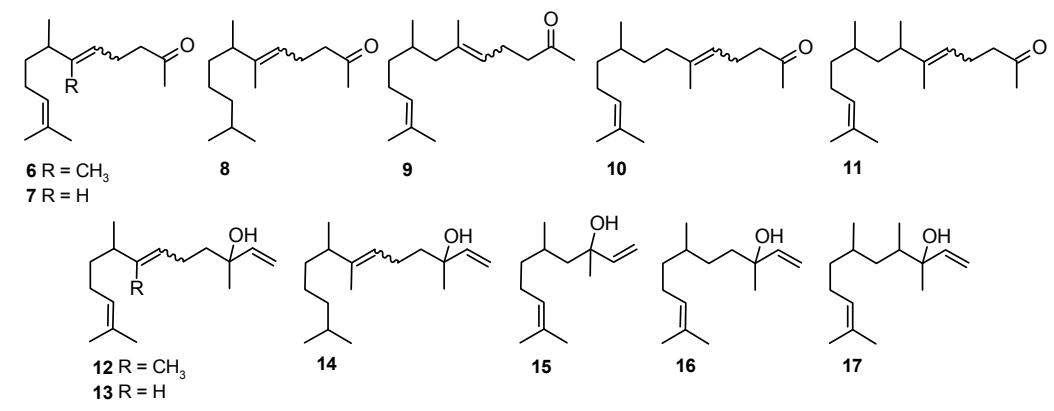

Figure 3. Compounds structurally related to geranyl acetone (6 to 11) and nerolidol (12 to 17 ).

\section{Results and Discussion}

\subsection{Synthetic Methodology}

Starting from the alcohols 12-17 [18], we obtained a series of compounds structurally related to farnesal (18-23) (Figure 4) by an oxidative rearrangement of tertiary allylic alcohols [21].

We observed that the obtained aldehydes exhibited high lability, which could somehow be confirmed by the dependence of the yield on the isolation method. The yields of the distilled products were $36 \%$ to $67 \%$, while for products purified by column chromatography on silica gel, the yields were $71 \%$ to 83\%. Furthermore, we found that the aldehydes $\mathbf{1 8}-\mathbf{2 3}$ were rather stable in the solutions. The $E / Z$ geometric isomer ratio, confirmed by GC and NMR analyses, of the rearranged C-C double bond was 2:1 for 18, 19, 20, 23, while for 21 and 22 it was $1: 1$ and 3:2, respectively. The most characteristic and diagnostic signal on the NMR spectra was the signal of the $\gamma$ methyl substituent. In the case of the $E$ isomer, the ${ }^{1} \mathrm{H}$ chemical shift, due to deshielding by the carbonyl group, was higher (ca. $2.1 \mathrm{ppm}$ and ca. $1.9 \mathrm{ppm}$ for the $Z$ isomer). On the other hand, in the $E$ isomer, the signal of the carbon atom, due to the steric effect, was shifted upfield ( $c a .17 \mathrm{ppm}$ and $c a .25 \mathrm{ppm}$ for the $Z$ isomer).

The scent of the compounds structurally related to farnesal, or rather its absence, was surprising. The only exception was the odour of $\mathbf{2 1}$, which was intense, floral with fatty and melon notes, and of $\mathbf{2 3}$, which was geranyl acetone-like (green, fruity, waxy and woody). 

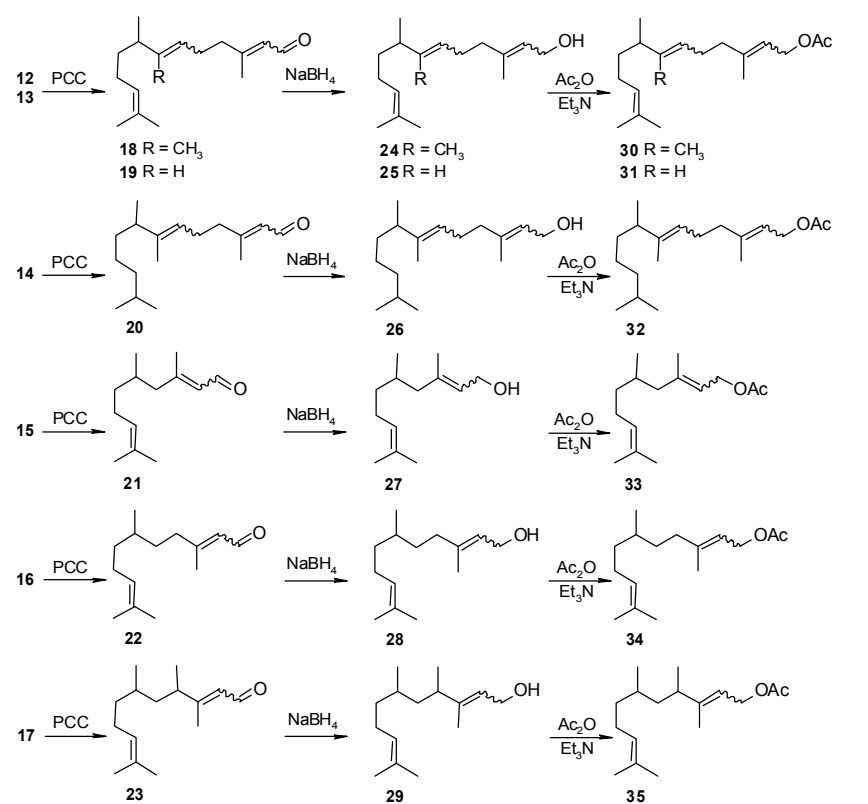

Figure 4. Synthesis of compounds structurally related to farnesal (18 to $\mathbf{2 3}$ ), farnesol ( 24 to $\mathbf{2 9}$ ) and farnesyl acetate (30 to $\mathbf{3 5})$.

The obtained aldehydes reduced with sodium borohydride in the usual manner yielded compounds structurally related to farnesol (47\% to $97 \%)$. The scent of the products was faint and floral, except for 29, which was odourless.

Subsequent esterification with acetic anhydride in the presence of triethylamine gave compounds structurally related to farnesyl acetate (yield 69\% to 90\%) which, just as the compounds structurally related to farnesal, were generally odourless but with one exception. Compound $\mathbf{3 5}$ had a very faint quince-like scent.

For all compounds which had the scent, we performed additionally GC-olfactometry experiments. For the compounds structurally related to both geranyl acetone and nerolidol [18], we did not observe significant differences in the odour description of the isomers.

\subsection{Antibacterial Activity of the Terpenoids and Their Structurally Related Compounds}

All of the obtained compounds and the parent terpenes were subjected to an evaluation of their antibacterial activity (Table 1). Data for geranyl acetone, nerolidol, ketones $\mathbf{6}$ to $\mathbf{1 1}$ and alcohols $\mathbf{1 2}$ to 17 were presented by us before [18].

Generally, the ketones $\mathbf{6}$ to $\mathbf{1 1}$ demonstrated the highest antibacterial activity against both standard strains from the Enterococcus genus and all of the tested Gram-negative bacteria with a Minimal Inhibitory Concentrations (MIC) between $12 \mu \mathrm{g} / \mathrm{mL}$ and $32 \mu \mathrm{g} / \mathrm{mL}$. Parent terpenoid-farnesol and some alcohols related to it and their acetates showed slightly similar activity. The most resistant to all of the tested compounds was the standard strain of Staphylococcus aureus ATCC 43300. Although Togashi et al. found that farnesol was active against Staphylococcus aureus FDA209P at concentrations of $10 \mu \mathrm{g} / \mathrm{mL}$ and higher, in their investigations the bacterial suspension contained $1 \times 10^{5} \mathrm{CFU}$ and the culture was incubated for $48 \mathrm{~h}$ with shaking and monitored turbidimetrically [2]. On the other hand, Jin et al. stated that farnesol had an inhibiting activity against Mycobacterium smegmatis mc ${ }^{2} 155$ ATCC 700084 with 
a MIC value at $64 \mu \mathrm{g} / \mathrm{mL}$ by micro-dilution and in accordance with NCCLS guidelines [22]. The MIC values obtained in our research for farnesol were from $16 \mu \mathrm{g} / \mathrm{mL}$ to $52 \mu \mathrm{g} / \mathrm{mL}$ against all of the tested standard strains. The other tested terpenoids and their structurally related compounds had an inhibiting activity against standard bacteria at a concentration between $12 \mu \mathrm{g} / \mathrm{mL}$ and $54 \mu \mathrm{g} / \mathrm{mL}$.

For synthesised compounds we also obtained by column chromatography $(E)-(Z)$-isomer enriched fractions containing $\geq 85 \%$ of the appropriate isomer according to the $\mathrm{GC}$, but the determined bioactivity (antimicrobial and cytotoxicity) did not differ significantly from that obtained for the mixtures (data not presented). Ciproflaxicin and gentamicin were used as the control for the reference strains.

Table 1. Antibacterial activity of structurally related compounds and parent terpenes against Gram-positive and Gramnegative reference strains.

\begin{tabular}{|c|c|c|c|c|c|c|}
\hline \multirow[b]{3}{*}{ Compound } & \multicolumn{6}{|c|}{ Minimum Inhibitory Concentrations MIC $(\mu \mathrm{g} / \mathrm{mL})$} \\
\hline & \multicolumn{3}{|c|}{ Gram-Positive Bacteria } & \multicolumn{3}{|c|}{ Gram-Negative Bacteria } \\
\hline & $\begin{array}{c}\text { Staphylococcus } \\
\text { aureus ATCC } \\
43300 \\
\end{array}$ & $\begin{array}{c}\text { Enterococcus } \\
\text { faecalis ATCC } \\
51299 \\
\end{array}$ & $\begin{array}{c}\text { Enterococcus } \\
\text { faecium АТCC } \\
35667 \\
\end{array}$ & $\begin{array}{c}\text { Escherichia } \\
\text { coli ATCC } \\
25922 \\
\end{array}$ & $\begin{array}{c}\text { Klebsiella } \\
\text { pneumoniae } \\
\text { ATCC } 700603 \\
\end{array}$ & $\begin{array}{c}\text { Acinetobacter } \\
\text { baumannii } \\
\text { ATCC } 19606\end{array}$ \\
\hline Geranyl acetone (1) & 48 & 36 & 28 & 26 & 18 & 18 \\
\hline 6 & 26 & 18 & 16 & 14 & 14 & 12 \\
\hline 7 & 26 & 16 & 18 & 16 & 16 & 14 \\
\hline 8 & 38 & 26 & 28 & 18 & 18 & 22 \\
\hline 9 & 28 & 18 & 14 & 28 & 18 & 16 \\
\hline 10 & 46 & 26 & 18 & 32 & 18 & 16 \\
\hline 11 & 26 & 22 & 18 & 28 & 28 & 14 \\
\hline Nerolidol (2) & 48 & 38 & 32 & 46 & 16 & 26 \\
\hline 12 & 48 & 46 & 42 & 40 & 28 & 26 \\
\hline 13 & 46 & 42 & 38 & 40 & 20 & 22 \\
\hline 14 & 48 & 38 & 36 & 38 & 18 & 28 \\
\hline 15 & 46 & 48 & 38 & 28 & 16 & 16 \\
\hline 16 & 48 & 38 & 36 & 32 & 24 & 22 \\
\hline 17 & 48 & 38 & 38 & 46 & 18 & 16 \\
\hline Farnesal (3) & 24 & 22 & 36 & 46 & 44 & 36 \\
\hline 18 & 18 & 22 & 28 & 52 & 46 & 46 \\
\hline 19 & 28 & 34 & 38 & 44 & 36 & 42 \\
\hline 20 & 22 & 20 & 32 & 48 & 38 & 38 \\
\hline 21 & 32 & 38 & 42 & 54 & 48 & 52 \\
\hline 22 & 26 & 24 & 46 & 44 & 36 & 36 \\
\hline 23 & 28 & 26 & 36 & 46 & 34 & 36 \\
\hline Farnesol (4) & 26 & 18 & 16 & 28 & 16 & 18 \\
\hline 24 & 22 & 18 & 32 & 52 & 44 & 40 \\
\hline 25 & 28 & 32 & 34 & 50 & 48 & 44 \\
\hline 26 & 32 & 30 & 36 & 48 & 42 & 38 \\
\hline 27 & 28 & 26 & 18 & 36 & 18 & 34 \\
\hline 28 & 26 & 18 & 16 & 28 & 16 & 18 \\
\hline 29 & 28 & 22 & 18 & 38 & 36 & 32 \\
\hline
\end{tabular}


Table 1. Cont.

\begin{tabular}{|c|c|c|c|c|c|c|}
\hline \multirow[b]{3}{*}{ Compound } & \multicolumn{6}{|c|}{ Minimum Inhibitory Concentrations MIC $(\mu \mathrm{g} / \mathrm{mL})$} \\
\hline & \multicolumn{3}{|c|}{ Gram-Positive Bacteria } & \multicolumn{3}{|c|}{ Gram-Negative Bacteria } \\
\hline & $\begin{array}{c}\text { Staphylococcus } \\
\text { aureus ATCC } \\
43300 \\
\end{array}$ & $\begin{array}{c}\text { Enterococcus } \\
\text { faecalis } \\
\text { ATCC } 51299 \\
\end{array}$ & $\begin{array}{c}\text { Enterococcus } \\
\text { faecium } \\
\text { АТСC } 35667 \\
\end{array}$ & $\begin{array}{c}\text { Escherichia } \\
\text { coli ATCC } \\
25922 \\
\end{array}$ & $\begin{array}{c}\text { Klebsiella } \\
\text { pneumoniae } \\
\text { ATCC } 700603\end{array}$ & $\begin{array}{c}\text { Acinetobacter } \\
\text { baumannii } \\
\text { ATCC } 19606\end{array}$ \\
\hline Farnesyl acetate (5) & 28 & 20 & 20 & 28 & 22 & 22 \\
\hline 30 & 30 & 24 & 18 & 30 & 24 & 24 \\
\hline 31 & 24 & 20 & 20 & 26 & 22 & 18 \\
\hline 32 & 28 & 22 & 20 & 28 & 18 & 22 \\
\hline 33 & 26 & 18 & 16 & 26 & 18 & 22 \\
\hline 34 & 32 & 20 & 18 & 18 & 20 & 18 \\
\hline 35 & 34 & 16 & 14 & 16 & 18 & 12 \\
\hline Ciprofloxacin & 8 & 2 & 8 & 4 & 2 & 4 \\
\hline Gentamicin & 16 & $>64 *$ & 32 & 4 & 32 & 32 \\
\hline
\end{tabular}

Pharmacophores

Having numerous data regarding the antimicrobial activity (MICs), we determined the possible pharmacophore models that define the activity of the described compounds (Figures 5 to 10).

The aldehyde 18 shows the highest activity against Staphylococcus aureus ATCC 43300 and the pharmacophore is defined by one hydrogen-bond acceptor (HBA, green) which is surrounded by the four excluded volumes (EV, grey) and two hydrophobes (H, cyan) comprising the chain (Figure 4). One of them is in the line designated by the hydrogen-bond acceptor at a distance $5.7 \AA$ from it, and the other is at a distance $12.4 \AA$ from HBA. The least active compounds $(\mathbf{1}, \mathbf{2}, \mathbf{1 2}, \mathbf{1 4}, 16$ and 17), in their probable and favourable energy conformations, do not fill one hydrophobe, more distant from hydrogen-bond acceptor. Geranyl acetone (1) is too short. In the case of nerolidol (2) and its structurally related alcohols $(\mathbf{1 2}, \mathbf{1 4}, 16$ and 17) closer to HBA, hydrophobe is filled with vinyl moiety which makes it impossible to further fill hydrophobe.
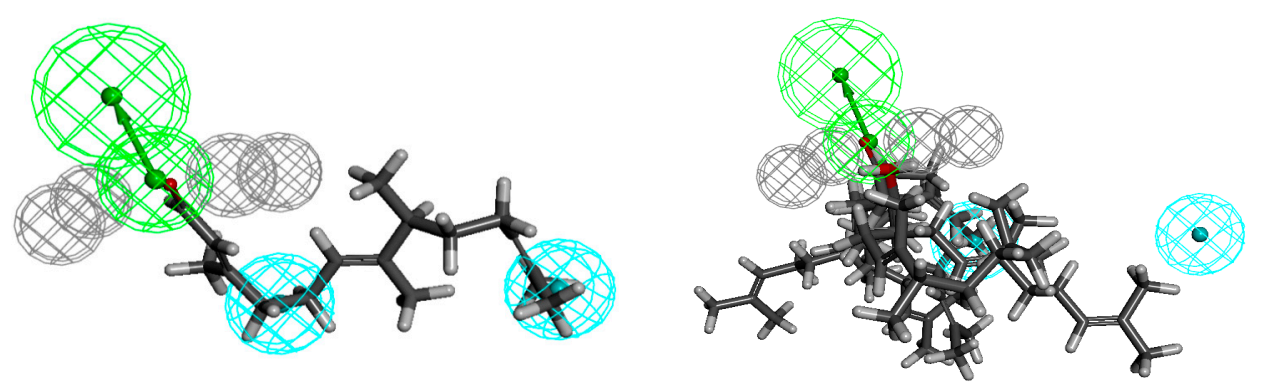

Figure 5. Aldehyde 18 aligned to the pharmacophore model of Staphylococcus aureus active compounds (on the left), the least active ones 1, 2, 12, 14, 16 and 17 (on the right).

The pharmacophore model of Enterococcus faecalis active compounds (Figure 6) consists of one HBA, two hydrophobes and five excluded volumes. Near the hydrogen bond acceptor there should be no steric hindrance, which indicates the presence of four excluded volumes nearby. The distances 
from HBA to the hydrophobes are 5.8 and 7.2 $\AA$. In this case, as in the pharmacophore model of Staphylococcus aureus active compounds, the least active compounds do not fill one hydrophobe, the cause are the steric and conformational factors. Furthermore, in the case of the least active ones structurally related to nerolidol 12 and 15, it can be assumed that the short length of the molecule in conjunction with the position of the functional group which is more in the middle of the chain causes lowering of the activity of these compounds. In turn, in the case of the most active ketone $\mathbf{7}$ and acetate 35, connection of suitable chain length and exposition of the functional group makes these compounds more active.
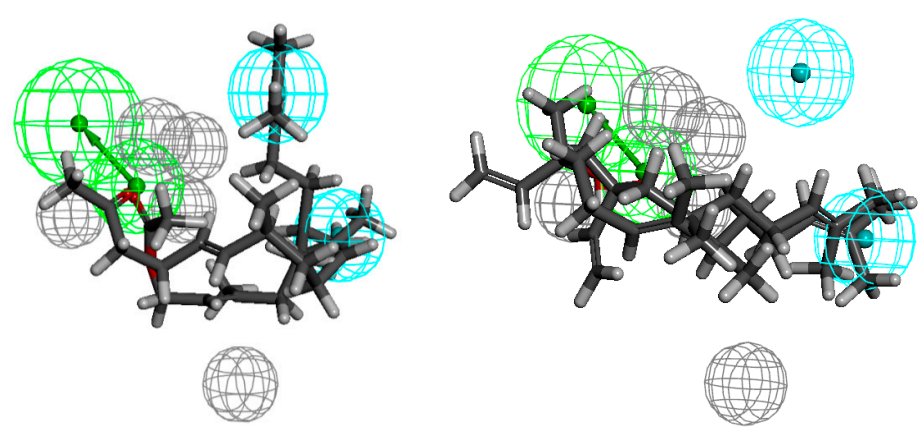

Figure 6. Compounds structurally related to geranyl acetone and farnesyl acetate (7 and 35) aligned to the pharmacophore model of Enterococcus faecalis active compounds (on the left), the least active ones $\mathbf{1 2}$ and $\mathbf{1 5}$ (on the right).

In the set of analysed compounds, the most potent against Enterococcus faecium are ketone $\mathbf{9}$ and acetate 35. The pharmacophore comprises one hydrogen-bond acceptor, two hydrophobes and five excluded volumes (Figure 7). Both hydrophobes are in the line perpendicular to the line determined by HBA and the distances are 6.9 and $10.0 \AA$. The lack of filling of one hydrophobe is the cause of low activity of compounds $\mathbf{1 2}$ and $\mathbf{2 2}$. This is due to the same considerations as in the two previous cases.
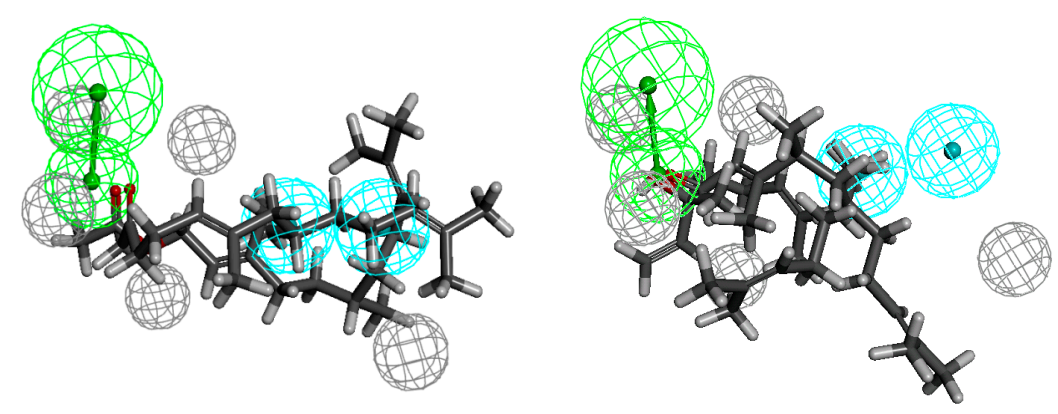

Figure 7. Compounds structurally related to geranyl acetone and farnesyl acetate $\mathbf{9}$ and $\mathbf{3 5}$ aligned to the pharmacophore model of Enterococcus faecium active compounds (on the left), the least active ones $\mathbf{1 2}$ and $\mathbf{2 2}$ (on the right).

Ketone 6 shows the highest activity against the Gram-negative bacteria strains: Escherichia coli, Klebsiella pneumoniae and Acinetobacter baumannii. Acetate 35 shows equal activity towards the last-mentioned strain. The pharmacophores are defined by one hydrogen-bond acceptor, three (Escherichia coli) or two (two other strains) hydrophobes and five (Klebsiella pneumoniae) or two excluded volumes (Figures 8-10, respectively). In the case of E. coli, the hydrophobes include methyl 
substituents at C-6 and C-7 and an isobutenyl moiety; in the case of $K$. pneumoniae the methyl groups seem to play an important role and they fit into the hydrophobes. In turn, the pharmacophore describing the spatial requirement for A. baumannii active molecules indicates the important role of methyl substituent at C-7 and the isobutenyl moiety. The distances from HBA to the hydrophobes are 5.5, 7.2, 9.0 and 3.4, 4.2 and 5.8, $6.1 \AA$ (Escherichia coli and Klebsiella pneumoniae and Acinetobacter baumannii, respectively). In the case of pharmacophores with regard to the compounds least active against Gram-negative bacteria, the problem seems to be the position of the functional group in the chain. While both hydrophobes are filled, in each case the functional group passes the hydrogen-bond acceptor. While for compounds active against Gram-positive bacteria the exposition of the functional group is beneficial, here it does not bring the desired effect.
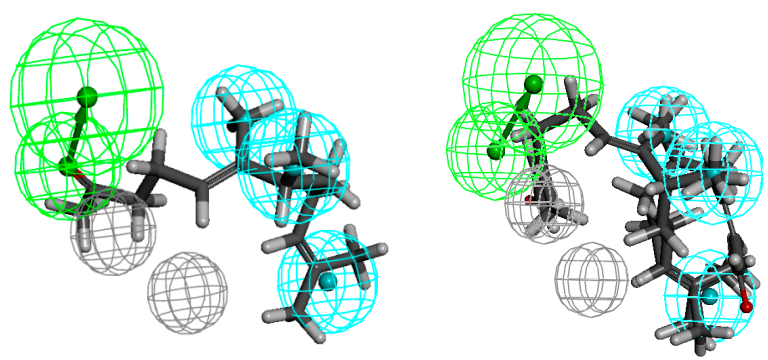

Figure 8. Compound structurally related to geranyl acetone $\mathbf{6}$ aligned to the pharmacophore model of Escherichia coli active compounds (on the left), the least active ones $\mathbf{1 8}$ and $\mathbf{2 1}$ (on the right).
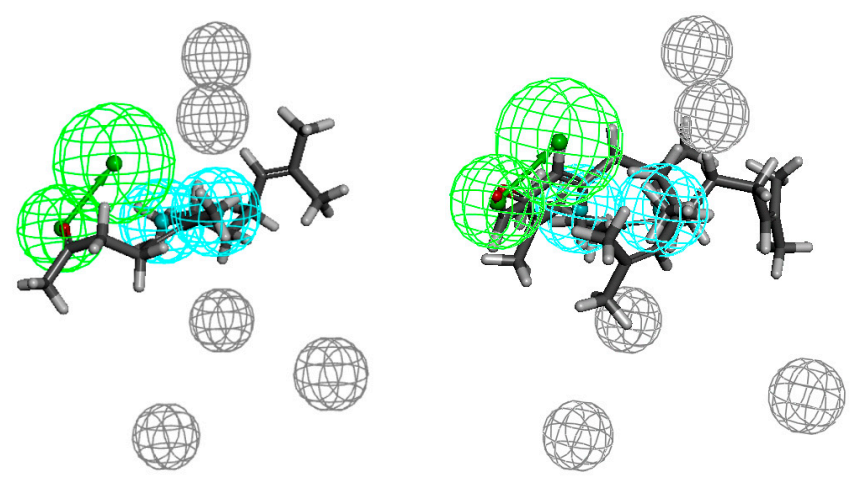

Figure 9. Ketone 6 aligned to the pharmacophore model of Klebsiella pneumoniae active compounds (on the left), the least active ones $\mathbf{1 8}$ and $\mathbf{2 1}$ (on the right).
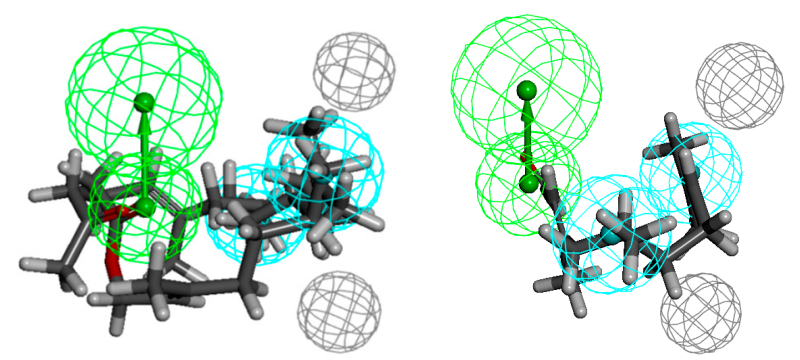

Figure 10. Compounds structurally related to geranyl acetone and farnesyl acetate 6 and $\mathbf{3 5}$ aligned to the pharmacophore model of Acinetobacter baumannii active compounds (on the left), the least active ones 21 (on the right). 
The pharmacophore modelling was conducted additionally only for the most active substances (Figure 11). The result obtained confirmed the previously described observations regarding the required length of the chain and exposition of the functional group.

Compared to the more general models obtained by using all of the compounds described herein, the above can be considered as more restrictive. Although the appearance of these models is different, their analysis leads to identical conclusions. The compounds with longer chains have higher antimicrobial activity. Additionally, exposition of the functional group is once the favourable factor (activity against Gram-positive bacteria) while it is unfavourable at another time (activity against Gram-negative bacteria).

Moreover, in the above described steric conditions, it can be seen that the $\beta$-methyl substituent also plays an important role (in the case of $S$. aureus).

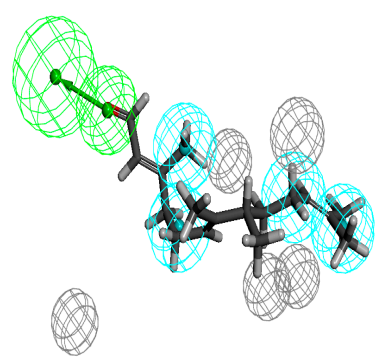

(a)

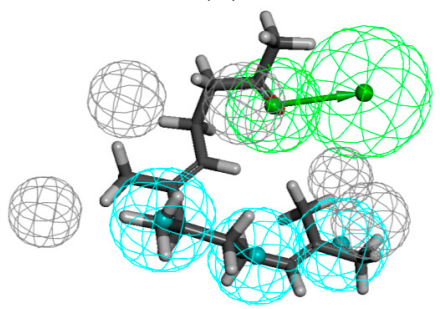

(d)

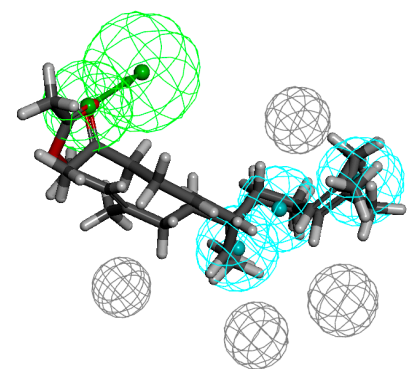

(b)

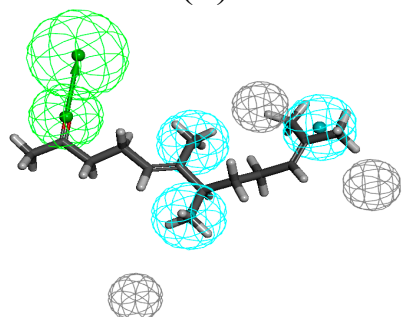

(e)

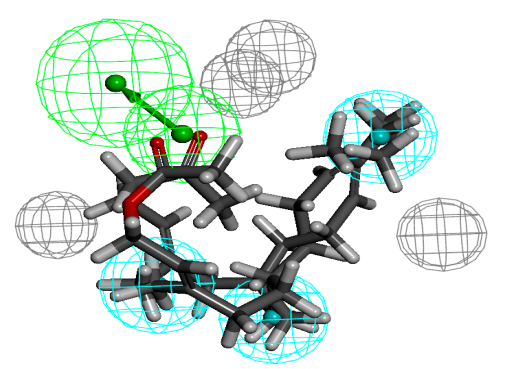

(c)

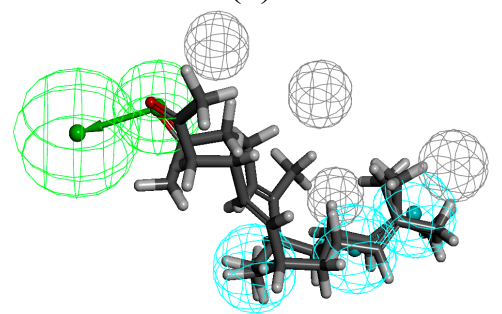

(f)

Figure 11. The pharmacophore models of the most active compounds against Gram-positive: S. aureus (a); E. faecalis (b); E. faecium (c) and most active compounds against Gram-negative strains: E. coli (d); K. pneumoniae (e); A. baumannii (f).

\subsection{Cytotoxicity of the Parent Terpenes and Structurally Related Compounds}

All of the obtained compounds and parent terpenes as positive controls were additionally subjected to cytotoxicity (MTT test) using a popular in vitro model of human leukaemia HL-60 cells. We obtained the cytotoxic activities of geranyl acetone and nerolidol that were close to those reported elsewhere [11], although they possessed lower biological effectiveness. The $\mathrm{IC}_{50}$ level (interpolated), which means the compound concentration required to suppress cell viability by $50 \%$, was $c a$. $135 \mu \mathrm{M}$ and $295 \mu \mathrm{M}$ for nerolidol (2) and geranyl acetone (1), respectively. Our studies showed that nerolidol and synthetic structurally related compounds (12 to 17) were more active inhibitors of cellular dehydrogenases as compared to compounds based on the geranyl acetone structure (Table 2). The IC 50 values for the alcohols 12 to 17 were in the range of $c a .500 \mu \mathrm{M}$ to $750 \mu \mathrm{M}$, except for $16(c a .1000 \mu \mathrm{M})$, while for geranyl acetone and synthetic ketones 6 to 11, they were higher than $1000 \mu \mathrm{M}$. 
Table 2. Concentration-response effects (viability) of the studied compounds on cancer and regular cells metabolic activity after $24 \mathrm{~h}$.

\begin{tabular}{|c|c|c|c|c|c|c|}
\hline \multirow[b]{2}{*}{ Compound } & \multicolumn{3}{|c|}{ Cancer Cell Lines } & \multicolumn{3}{|c|}{ Normal Cell Lines } \\
\hline & $\begin{array}{c}\text { Malignant } \\
\text { Melanoma } \\
\text { MEWO }\end{array}$ & $\begin{array}{c}\text { Colorectal } \\
\text { Adenocarcinoma } \\
\text { HT29 } \\
\end{array}$ & $\begin{array}{c}\text { Promyelocytic } \\
\text { Leukaemia } \\
\text { HL-60 } \\
\end{array}$ & $\begin{array}{c}\text { Fibroblasts } \\
\text { HFIG }\end{array}$ & $\begin{array}{c}\text { Keratinocytes } \\
\text { HaCaT }\end{array}$ & $\begin{array}{c}\text { Epithelium of } \\
\text { the Small } \\
\text { Intestine IEC6 }\end{array}$ \\
\hline Geranyl acetone (1) & $93 \% \pm 4 \%$ & $98 \% \pm 8 \%$ & 295 & $82 \% \pm 7 \%$ & $89 \% \pm 3 \%$ & $79 \% \pm 6 \%$ \\
\hline 6 & $102 \% \pm 5 \%$ & $102 \% \pm 6 \%$ & $67 \% \pm 5 \%$ & $83 \% \pm 2 \%$ & $118 \% \pm 5 \%$ & $95 \% \pm 7 \%$ \\
\hline 7 & $99 \% \pm 2 \%$ & $98 \% \pm 2 \%$ & $67 \% \pm 5 \%$ & $92 \% \pm 8 \%$ & $101 \% \pm 7 \%$ & $82 \% \pm 3 \%$ \\
\hline 8 & $94 \% \pm 5 \%$ & $111 \% \pm 3 \%$ & $72 \% \pm 5 \%$ & $81 \% \pm 9 \%$ & $90 \% \pm 2 \%$ & $97 \% \pm 5 \%$ \\
\hline 9 & $83 \% \pm 9 \%$ & $107 \% \pm 8 \%$ & $69 \% \pm 0 \%$ & $85 \% \pm 6 \%$ & $89 \% \pm 4 \%$ & $76 \% \pm 2 \%$ \\
\hline 10 & $93 \% \pm 5 \%$ & $103 \% \pm 9 \%$ & $62 \% \pm 8 \%$ & $98 \% \pm 7 \%$ & $112 \% \pm 8 \%$ & $78 \% \pm 4 \%$ \\
\hline 11 & $112 \% \pm 4 \%$ & $92 \% \pm 1 \%$ & $59 \% \pm 7 \%$ & $102 \% \pm 3 \%$ & $100 \% \pm 5 \%$ & $81 \% \pm 5 \%$ \\
\hline Nerolidol (2) & $99 \% \pm 3 \%$ & $103 \% \pm 8 \%$ & 135 & $75 \% \pm 6 \%$ & $102 \pm 5 \%$ & $76 \% \pm 9 \%$ \\
\hline 12 & $97 \% \pm 5 \%$ & $97 \% \pm 3$ & 500 & $110 \% \pm 7 \%$ & $101 \% \pm 6 \%$ & $73 \% \pm 8 \%$ \\
\hline 13 & $83 \% \pm 5 \%$ & $99 \% \pm 6 \%$ & 400 & $87 \% \pm 7 \%$ & $87 \% \pm 6 \%$ & $96 \% \pm 5 \%$ \\
\hline 14 & $99 \% \pm 6 \%$ & $112 \% \pm 5 \%$ & 750 & $99 \% \pm 4 \%$ & $106 \% \pm 5 \%$ & $65 \% \pm 8 \%$ \\
\hline 15 & $104 \% \pm 6 \%$ & $104 \% \pm 7 \%$ & 750 & $96 \% \pm 5 \%$ & $90 \% \pm 7 \%$ & $110 \% \pm 3 \%$ \\
\hline 16 & $100 \% \pm 7 \%$ & $102 \% \pm 3 \%$ & 950 & $106 \% \pm 5 \%$ & $89 \% \pm 4 \%$ & $113 \% \pm 2 \%$ \\
\hline 17 & $112 \% \pm 0 \%$ & $108 \% \pm 4 \%$ & 750 & $87 \% \pm 5 \%$ & $95 \% \pm 0 \%$ & $98 \% \pm 5 \%$ \\
\hline Farnesal (3) & 467 & $110 \% \pm 9 \%$ & 363 & 650 & 702 & $85 \% \pm 2 \%$ \\
\hline 18 & 630 & $98 \% \pm 9 \%$ & 502 & 690 & 800 & $79 \% \pm 6 \%$ \\
\hline 19 & 600 & $96 \% \pm 2 \%$ & 550 & 750 & 850 & $94 \% \pm 4 \%$ \\
\hline 20 & 690 & $82 \% \pm 6 \%$ & 480 & 610 & 850 & $64 \% \pm 7 \%$ \\
\hline 21 & 640 & $98 \% \pm 6 \%$ & 600 & 830 & 830 & $91 \% \pm 3 \%$ \\
\hline 22 & 700 & $93 \% \pm 3 \%$ & 600 & 740 & 880 & $76 \% \pm 3 \%$ \\
\hline 23 & 730 & $87 \% \pm 7 \%$ & 630 & 800 & 900 & $82 \% \pm 5 \%$ \\
\hline Farnesol (4) & 378 & 930 & 54 & 350 & 489 & $58 \% \pm 8 \%$ \\
\hline 24 & 512 & $78 \% \pm 6 \%$ & 100 & 390 & 686 & $85 \% \pm 5 \%$ \\
\hline 25 & 500 & $108 \% \pm 11 \%$ & 167 & 454 & 667 & $82 \% \pm 2 \%$ \\
\hline 26 & 495 & $96 \% \pm 5 \%$ & 145 & 531 & 620 & $76 \% \pm 3 \%$ \\
\hline 27 & 456 & $106 \% \pm 2 \%$ & 143 & 489 & 687 & $93 \% \pm 5 \%$ \\
\hline 28 & 512 & $93 \% \pm 8 \%$ & 198 & 687 & 698 & $101 \% \pm 4 \%$ \\
\hline 29 & $\mathbf{5 8 7}$ & $82 \% \pm 2 \%$ & 252 & 756 & 946 & $103 \% \pm 2 \%$ \\
\hline Farnesyl acetate (5) & 734 & $105 \% \pm 3 \%$ & 121 & $98 \% \pm 7 \%$ & $102 \% \pm 3 \%$ & $78 \% \pm 7 \%$ \\
\hline 30 & 850 & $96 \% \pm 4 \%$ & 289 & $105 \% \pm 3 \%$ & 900 & $86 \% \pm 6 \%$ \\
\hline 31 & 930 & $107 \% \pm 8 \%$ & 350 & 850 & $98 \% \pm 7 \%$ & $94 \% \pm 5 \%$ \\
\hline 32 & 800 & $103 \% \pm 7 \%$ & 278 & 980 & 950 & $92 \% \pm 4 \%$ \\
\hline 33 & $103 \% \pm 5 \%$ & $110 \% \pm 9 \%$ & 400 & $100 \% \pm 6 \%$ & $101 \% \pm 6 \%$ & $95 \% \pm 5 \%$ \\
\hline 34 & $98 \% \pm 6 \%$ & $98 \% \pm 3 \%$ & 312 & $99 \% \pm 3 \%$ & $110 \% \pm 5 \%$ & $79 \% \pm 3 \%$ \\
\hline 35 & $112 \% \pm 5 \%$ & $83 \% \pm 5 \%$ & 343 & $87 \% \pm 8 \%$ & $102 \% \pm 4 \%$ & $71 \% \pm 4 \%$ \\
\hline
\end{tabular}

The half maximal inhibitory concentrations ( $\mathrm{IC}_{50}$ ) after $24 \mathrm{~h}$, interpolated values (bolded). Range of the concentrations $10-1000 \mu \mathrm{M}$. If the $\mathrm{IC}_{50}$ exceeded $1000 \mu \mathrm{M}$ viability [\%] \pm standard deviation at $1000 \mu \mathrm{M}$ is given.

The very high cytotoxic activity of farnesol, and thus its potential use as an anticancer agent, was confirmed previously in studies performed on non-small cell lung cancer cells (H460 and A549), 
which showed that the IC50 values for both cell lines were approximately $4.5 \mu \mathrm{M}$ [14]. The comparison of cell lines viability results obtained for all newly synthesised compounds revealed that farnesol and its structurally related compounds had the highest biological activity, especially against the HL-60 cell line, although none of the synthesised compound was better than farnesol (IC50 $=54 \mu \mathrm{M})$. The compounds structurally related to farnesal and farnesyl acetate were not as active as farnesol, however, they also inhibited the metabolic activity of leukaemia cells at relatively high concentrations $\left(\mathrm{IC}_{50}=289\right.$ to $630 \mu \mathrm{M})$. All of the studied compounds were practically harmless against epithelial cell lines of digestive-system origin (colorectal adenocarcinoma HT29 and small intestine epithelium IEC6).

On the other hand, by taking into account the potential use of these new synthesised compounds in the flavour and fragrance industry, there was a need to perform cytotoxicity studies on cells of skin origin. It is known that the skin consists of different types of cells, such as keratinocytes, melanocytes and fibroblasts; thus the compounds' influence on cellular metabolic activity was measured on MEWO melanocytes, immortalised keratinocytes $\mathrm{HaCaT}$ and normal human fibroblast cell lines (HFIG). In this case, the $\mathrm{IC}_{50}$ levels against the cell lines used could not be obtained for geranyl acetone, nerolidol and their structurally related compounds within the range of the tested compound concentrations; thus these values were higher than $1000 \mu \mathrm{M}$. What is more, the maximum metabolic inhibitory effect observed for the highest compound concentration did not exceed 15\% (data not shown). Studies performed by Pohlit et al. indicated no toxicity of nerolidol against other human melanoma MDA/MB-435 cell lines and colon carcinoma HCT-8 cells [12]. These data suggest that the obtained compounds could probably be safely used in flavour and fragrance compositions. The compounds structurally related to farnesol, farnesal and farnesyl acetate influenced skin cells viability and their $\mathrm{IC}_{50}$ values were in the range of 350 to $990 \mu \mathrm{M}$; the keratinocytes were the least sensitive from the studied cell lines, however, the results obtained for normal fibroblasts and malignant cells were comparable.

When comparing the results it was important to emphasise that the HL-60 cell line was more sensitive to the tested compounds, whereas skin and digestive-system originated cells (both normal and immortalised) did not show a significant reduction of metabolic activity. Using HL-60 cells as a single cellular model may give a false evaluation of the biological activity of these compounds.

\section{Experimental Section}

\subsection{General}

The reagents were generally of commercial grade and were used without further purification. Column chromatography on silica gel for TLC with hexane: ethyl acetate (9:1) as the mobile phase (unless otherwise indicated). GC-MS (Pegasus 4D, LECO, St. Joseph, MI, USA) was performed with a chromatograph coupled with an MS detector, equipped with a BPX-5 (SGE Analytical Science, Ringwood, Melbourne, Vic, Australia) capillary column (30 m long, $0.25 \mathrm{~mm}$ inside diameter, $0.25 \mu \mathrm{m}$ film thickness); the temperature programme was 50 to $300{ }^{\circ} \mathrm{C}$ at $4 \% \mathrm{~min}$, carrier gas: helium, flow $1 \mathrm{~mL} / \mathrm{min}$. ${ }^{1} \mathrm{H}-\mathrm{NMR}(250 \mathrm{MHz})$ and ${ }^{13} \mathrm{C}-\mathrm{NMR}(63 \mathrm{MHz})$ of the fractions enriched with the individual $E / Z$ isomers and racemates in the case of 23, 29 and 35 were recorded using a Bruker DPX-250 Avance spectrometer in $\mathrm{CDCl}_{3}$ solutions with TMS as the internal standard. Some NMR spectra were recorded using a Bruker Advance II Plus $700 \mathrm{MHz}$ (BRUKER, Billerica, MA, USA). 
${ }^{13} \mathrm{C}-\mathrm{NMR}$ multiplicity was determined using DEPT experiments. Purity of the products was confirmed by both GC and TLC analyses. The samples on a blotter (10\% ethanolic solutions) were judged by nine experienced panellists to evaluate the odour characteristics of the obtained products.

\subsubsection{Antimicrobial Test}

The standard strains, Gram-positive: Staphylococcus aureus ATCC 433000, Enterococcus faecalis Van B ATCC 51299 and Enterococcus faecium VA sensitive ATCC 35667, and Gram-negative: Escherichia coli ATCC 25922, Klebsiella pneumoniae ATCC 700603 and Acinetobacter baumannii ATCC 19606, came from a collection of the Environmental Biology Department, Medical University of Łódź. The standard strains were cultivated in Columbia Agar Medium and incubated at $37^{\circ} \mathrm{C}$ for $24 \mathrm{~h}$ in aerobic conditions.

The antibacterial activity of the racemates and $E / Z$-mixtures was investigated using the micro-dilution broth method [23]. The compounds were diluted in ethanol. This stock solution was mixed with $100 \mu \mathrm{L}$ of Mueller-Hinton broth to obtain concentrations from $10 \mu \mathrm{g} / \mathrm{mL}$ to $80 \mu \mathrm{g} / \mathrm{mL}$. The mixtures were then transferred to 96-well microtiter plates. The microbial suspension was standardised to a cell density of $1.5 \times 10^{8} \mathrm{CFU}$, which was equal to an optical density of 0.5 on the Mc Farland scale by a bio-Merieux densitometer; one well was filled with broth only to act as a control for strain growth. The Minimal Inhibitory Concentration (MIC) was determined as the lowest concentration of the compound which inhibited visible growth of bacteria after $24 \mathrm{~h}$ of incubation at $37{ }^{\circ} \mathrm{C}$ under aerobic conditions. The control media containing only alcohol at concentrations used in the dilutions of the compounds did not inhibit the growth of the standard.

\subsubsection{In Vitro Inhibition of Animal Cell Line Viability}

Cell lines and in vitro culture conditions: The human promyelocytic leukaemia cell line HL-60 was obtained from the Centre of Molecular and Macromolecular Biology in Łódź, Poland and was cultured in RPMI 1640 medium with 20\% heat-inactivated fetal bovine serum (FBS). To reduce spontaneous differentiation, the cells were never allowed to exceed a concentration of $1.0 \times 10^{6}$ cells $/ \mathrm{mL}$. The human keratinocyte cell line HaCaT was obtained from Cell Lines Service, Germany (CLS) and cultured in DMEM medium with 10\% FBS. Human colorectal adenocarcinoma HT29 and normal epithelial IEC-6 cell lines (from ATCC) were cultured in DMEM medium with 10\% FBS. The human skin melanoma cell line MEWO (from CLS) was cultured in DMEM:F12 supplemented with $2 \mathrm{mM}$ L-glutamine and 10\% FBS. Human fibroblasts from gingiva isolated from original tissue, HFIB-G, (from Provitro) were cultured in Quantum 333 (from Immunique). The media were supplemented with $100 \mathrm{U} / \mathrm{mL}$ penicillin and $100 \mu \mathrm{g} / \mathrm{mL}$ streptomycin; all media components were obtained from Life Technologies. The adherent cell lines used in the studies were seeded on microplates before they exceeded $80 \%$ of confluence. Cells were cultured at $37{ }^{\circ} \mathrm{C}$ in $5 \% \mathrm{CO}_{2}$ air atmosphere $/ 95 \%$ air atmosphere.

Cytotoxic activity: The cells (the density for HL-60 was $0.5 \times 10^{4}$ cells $/ 100 \mu \mathrm{L}$, otherwise it was $1 \times 10^{4}$ cells $/ 100 \mu \mathrm{L}$ ) were plated into each well of 96 -well microtiter plates and, after their attachment to the plate surface, treated with $10 \mu \mathrm{L}$ of the indicated concentrations of compounds for $24 \mathrm{~h}$. Viability was determined by MTT assay following the treatment. MTT (3-[4.5-dimethylthiazol-2-yl]2.5-diphenyltetrazolium bromide; Sigma, St. Louis, MO, USA) solution was added to each well and 
incubated for another $4 \mathrm{~h}$. The resulting MTT-formazan product was dissolved by the addition of lysis buffer (20\% SDS and 50\% DMF). The amount of formazan was determined by measuring absorbance at $570 \mathrm{~nm}$ with a Synergy 2 microplate reader (BioTek, Winooski, VT, USA) operated by the Gen5 program. The experiments were conducted three times with five replications. The results are expressed as an optical density ratio of the treatment to control. All data are presented as means \pm SD.

\subsubsection{Pharmacophore Modelling}

Optimised models of all possible isomers of described compounds (including parent terpenes) with the density functional theory (DFT) and ab initio molecular dynamics calculation at B3LYP/6-31G(d) (Gaussian 03W v. 6.1) were used as ligands in 3D QSAR pharmacophore modelling which was performed using Discovery Studio 3.0 Client software (Polish National Licence, BIOVIA, San Diego, CA, USA). MICs were used as the activity attribute. The value of uncertainty was set at 1.5 . The pharmacophore generation protocol settings were as follows (as recommended in the Discovery Studio 3D QSAR Pharmacophore Generation Manual and due to the modelling of relatively small molecules): the number of features (hydrogen bond acceptor, hydrogen bond donor, hydrophobic, positive and negative ionizable) from 0 to 5 ; maximum pharmacophores 10; minimum features 1 ; maximum features 5; minimum interfeature distance 1.5; maximum excluded volumes 5; minimum feature points 4; minimum subset points 4; conformation generation BEST; maximum conformations 255. From the resulting pool of generated pharmacophores, the one that characterized the highest correlation was chosen.

\subsection{General Method for Rearrangement of the Tertiary Allylic Alcohols Combined with Oxidation to} Aldehydes-Synthesis of Compounds Structurally Related to Farnesal (18-23)

A total of $340 \mathrm{mmol}$ of the appropriate allylic alcohol (12-17), $150 \mathrm{~mL}$ of dichloromethane and $50 \mathrm{~g}$ of silica gel was placed into a flask. During vigorous stirring, $410 \mathrm{mmol}$ of pyridinium chlorochromate (PCC) was added portion-wise. The temperature was maintained at $10{ }^{\circ} \mathrm{C}$. After addition, the stirring was continued for another $12 \mathrm{~h}$. After that time, $10 \mathrm{~mL}$ of methanol was added and the mixture was stirred again for $1 \mathrm{~h}$. The products were isolated by column chromatography with diethyl ether as eluent. Purity of the products according to the GC analysis was $88 \%-97 \%$. The obtained products (18-23) were additionally distilled or purified by column chromatography (see below).

\subsubsection{3,7,8,12-Tetramethyltrideca-2,6,11-trienal (18)}

Fractional distillation (boiling point $131-134{ }^{\circ} \mathrm{C} / 0.1$ Torr) gave the product with a yield $43 \%$. When the product was isolated by column chromatography on silica (hexane:ethyl acetate 96:4) the yield was 72\%. IR (ATR): 2961, 2922, 2856, 2765, 1674, 1633, 1445, 1377, 1156, 1121, $830 \mathrm{~cm}^{-1}$; ${ }^{1} \mathrm{H}-\mathrm{NMR}$ $\left(250 \mathrm{MHz}, \mathrm{CDCl}_{3}\right)$ Isomer $(2 Z, 6 Z) \delta: 9.90(\mathrm{~d}, J=8.2 \mathrm{~Hz}, 1 \mathrm{H}), 5.85(\mathrm{dd}, J=8.2 \mathrm{~Hz}, 1.2 \mathrm{~Hz}, 1 \mathrm{H}), 5.14-5.00$ (m, 2H), $2.56(\mathrm{dd}, J=15.1,7.5 \mathrm{~Hz}, 2 \mathrm{H}), 2.57-2.45(\mathrm{~m}, 1 \mathrm{H}), 2.28-2.16(\mathrm{~m}, 2 \mathrm{H}), 1.95(\mathrm{~d}, J=1.2 \mathrm{~Hz}$, $3 \mathrm{H}), 1.80(\mathrm{dd}, J=14.6 \mathrm{~Hz}, 7.1 \mathrm{~Hz}, 2 \mathrm{H}), 1.64(\mathrm{~s}, 3 \mathrm{H}), 1.54(\mathrm{~s}, 3 \mathrm{H}), 1.53(\mathrm{~s}, 3 \mathrm{H}), 1.37-1.20(\mathrm{~m}, 2 \mathrm{H})$, $0.92(\mathrm{~d}, J=6.9 \mathrm{~Hz}, 3 \mathrm{H})$; Isomer $(2 Z, 6 E) \delta: 9.88(\mathrm{~d}, J=8.2 \mathrm{~Hz}, 1 \mathrm{H}), 5.85(\mathrm{dd}, J=8.2 \mathrm{~Hz}, 1.2 \mathrm{~Hz}, 1 \mathrm{H})$, 5.14-5.00 (m, 2H), $2.57(\mathrm{t}, J=7.5 \mathrm{~Hz}, 3 \mathrm{H}), 2.28-2.16(\mathrm{~m}, 2 \mathrm{H}), 2.05(\mathrm{dd}, J=14.4 \mathrm{~Hz}, 6.9 \mathrm{~Hz}, 1 \mathrm{H})$, 
$1.96(\mathrm{~d}, J=1.2 \mathrm{~Hz}, 3 \mathrm{H}), 1.80(\mathrm{dd}, J=14.6 \mathrm{~Hz}, 7.1 \mathrm{~Hz}, 2 \mathrm{H}), 1.64(\mathrm{~s}, 3 \mathrm{H}), 1.54(\mathrm{~s}, 3 \mathrm{H}), 1.48(\mathrm{~s}, 3 \mathrm{H})$, $1.37-1.20(\mathrm{~m}, 2 \mathrm{H}), 0.92(\mathrm{~d}, J=6.9 \mathrm{~Hz}, 3 \mathrm{H})$; Isomer $(2 E, 6 Z) \delta: 9.95(\mathrm{~d}, J=8.1 \mathrm{~Hz}, 1 \mathrm{H}), 5.85(\mathrm{dd}$, $J=8.1 \mathrm{~Hz}, 1.1 \mathrm{~Hz}, 1 \mathrm{H}), 5.10-5.00(\mathrm{~m}, 2 \mathrm{H}), 2.62-2.48(\mathrm{~m}, 1 \mathrm{H}), 2.27-2.15(\mathrm{~m}, 4 \mathrm{H}), 2.14(\mathrm{~d}$, $J=1.1 \mathrm{~Hz}, 3 \mathrm{H}), 1.81(\mathrm{dd}, J=14.9 \mathrm{~Hz}, 7.1 \mathrm{~Hz}, 2 \mathrm{H}), 1.64(\mathrm{~s}, 3 \mathrm{H}), 1.54(\mathrm{~s}, 3 \mathrm{H}), 1.53(\mathrm{~s}, 3 \mathrm{H}), 1.39-1.16$ $(\mathrm{m}, 2 \mathrm{H}), 0.92(\mathrm{~d}, J=6.9 \mathrm{~Hz}, 3 \mathrm{H})$; Isomer $(2 E, 6 E) \delta: 9.95(\mathrm{~d}, J=8.1 \mathrm{~Hz}, 1 \mathrm{H}), 5.85(\mathrm{dd}, J=8.1 \mathrm{~Hz}$, $1.1 \mathrm{~Hz}, 1 \mathrm{H}), 5.10-5.00(\mathrm{~m}, 2 \mathrm{H}), 2.28-2.15(\mathrm{~m}, 4 \mathrm{H}), 2.14(\mathrm{~d}, J=1.1 \mathrm{~Hz}, 3 \mathrm{H}), 2.05(\mathrm{dd}, J=14.5 \mathrm{~Hz}$, $6.9 \mathrm{~Hz}, 1 \mathrm{H}), 1.81(\mathrm{dd}, J=14.9 \mathrm{~Hz}, 7.1 \mathrm{~Hz}, 2 \mathrm{H}), 1.64(\mathrm{~s}, 3 \mathrm{H}), 1.54$ (s, 3H), 1.48 (s, 3H), 1.39-1.16 (m, 2H), $0.92(\mathrm{~d}, J=6.9 \mathrm{~Hz}, 3 \mathrm{H}) ;{ }^{13} \mathrm{C}-\mathrm{NMR}\left(63 \mathrm{MHz}, \mathrm{CDCl}_{3}\right)$ Isomer $(2 Z, 6 Z) \delta: 190.5$ (d), $163.6(\mathrm{~s})$, $141.0(\mathrm{~s}), 131.2(\mathrm{~s}), 128.5(\mathrm{~d}), 124.5(\mathrm{~d}), 122.8(\mathrm{~d}), 34.7(\mathrm{t}), 33.4(\mathrm{~d}), 32.8(\mathrm{t}), 26.2(\mathrm{t}), 26.1(\mathrm{t}), 25.5$ (q), 24.9 (q), 19.1 (q), 17.8 (q), 17.5 (q); Isomer (2Z,6E) $\delta: 190.6$ (d), 163.8 (s), 141.2 (s), 130.9 (s), $128.5(\mathrm{~d}), 124.6(\mathrm{~d}), 121.5(\mathrm{~d}), 42.2(\mathrm{~d}), 34.9(\mathrm{t}), 32.4(\mathrm{t}), 26.7(\mathrm{t}), 26.0(\mathrm{t}), 25.5(\mathrm{q}), 25.3(\mathrm{q}), 19.5(\mathrm{q})$, 17.5 (q), 12.2 (q); Isomer (2E,6Z) $\delta$ : 191.0 (d), 163.6 (s), 140.4 (s), 131.1 (s), 127.3 (d), 124.5 (d), $123.0(\mathrm{~d}), 40.8(\mathrm{t}), 34.7(\mathrm{t}), 33.4(\mathrm{~d}), 26.1$ (t), 25.5 (q), 24.9 (t), 19.1 (q), 17.8 (q), 17.5 (q), 17.4 (q); Isomer $(2 E, 6 E) \delta: 191.0$ (d), 163.6 (s), 140.5 (s), 130.9 (s), 127.3 (d), 124.6 (d), 121.9 (d), 42.2 (d), $40.5(\mathrm{t}), 34.9(\mathrm{t}), 26.0(\mathrm{t}), 25.5(\mathrm{q}), 25.3(\mathrm{t}), 19.6(\mathrm{q}), 17.5(\mathrm{q}), 17.4(\mathrm{q}), 12.1(\mathrm{q}) ; \mathrm{MS}(70 \mathrm{eV}) \mathrm{m} / z(\%)$ Isomer (2Z,6Z) $248\left[\mathrm{M}^{+}(1), 82\right.$ (100), 69 (53), 95 (45), 41 (38), 109 (38), 55 (36), 67 (33), 81 (25), 83 (25), 149 (12), 121 (11), 137 (10), 167 (5), 205 (4); Isomer (2Z,6E) 248 [M] (1), 82 (100), 69 (45), 95 (30), 41 (29), 109 (29), 55 (28), 67 (27), 83 (21), 81 (20), 149 (8), 121 (7), 137 (6), 167 (5), 205 (2); Isomer (2E,6Z) $248[\mathrm{M}]^{+}(1), 82$ (100), 69 (53), 95 (35), 41 (33), 109 (30), 67 (30), 55 (29), 81 (22), 83 (22) 149 (10), 121 (8), 137 (7), 167 (5), 205 (2); Isomer (2E,6E) 248 [M] (1), 82 (100), 69 (40), 41 (26), 67 (26), 95 (25), 55 (24), 109 (23), 83 (19), 81 (17), 167 (7), 149 (6), 121 (5), 205 (1). Anal. Calcd for: $\mathrm{C}_{17} \mathrm{H}_{28} \mathrm{O}: \mathrm{C}, 82.20 ; \mathrm{H}, 11.36$. Found: $\mathrm{C}, 82.48 ; \mathrm{H}, 11.32$.

\subsection{2. (6E)-3,8,12-Trimethyltrideca-2,6,11-trienal (19)}

Column chromatography on silica gel (hexane:ethyl acetate 98:2) gave a yield of 71\%. IR (ATR) 2965, 2915, 2853, 2764, 1673, 1633, 1449, 1377, 1193, 1123, 970, $841 \mathrm{~cm}^{-1}$; ${ }^{1} \mathrm{H}-\mathrm{NMR}$ (250 MHz, $\left.\mathrm{CDCl}_{3}\right)$ Isomer $(2 Z, 6 E) \delta: 9.92(\mathrm{~d}, J=8.2 \mathrm{~Hz}, 1 \mathrm{H}), 5.88(\mathrm{dd}, J=8.2 \mathrm{~Hz}, 1.2 \mathrm{~Hz}, 1 \mathrm{H}), 5.36-5.29(\mathrm{~m}$, 2H), 5.08 (dqq, $J=7.1,1.1,1.1 \mathrm{~Hz}, 1 \mathrm{H}), 2.63(\mathrm{t}, J=7.5 \mathrm{~Hz}, 2 \mathrm{H}), 2.30-2.19(\mathrm{~m}, 2 \mathrm{H}), 2.11-2.01$ (m, $1 \mathrm{H}), 1.97(\mathrm{~d}, J=1.2 \mathrm{~Hz}, 3 \mathrm{H}), 1.96-1.86(\mathrm{~m}, 2 \mathrm{H}), 1.67$ (d, $J=1.1 \mathrm{~Hz}, 3 \mathrm{H}), 1.58(\mathrm{~s}, 3 \mathrm{H}), 1.26$ (dd, $J=15.3 \mathrm{~Hz}, 7.1 \mathrm{~Hz}, 2 \mathrm{H}), 0.94(\mathrm{~d}, J=6.7 \mathrm{~Hz}, 3 \mathrm{H})$; Isomer $(2 E, 6 E) \delta: 9.98(\mathrm{~d}, J=8.1 \mathrm{~Hz}, 1 \mathrm{H}), 5.87$ $(\mathrm{dd}, J=8.1 \mathrm{~Hz}, 1.2 \mathrm{~Hz}, 1 \mathrm{H}), 5.35-5.28(\mathrm{~m}, 2 \mathrm{H}), 5.07$ (dqq, $J=7.1,1.0,1.0 \mathrm{~Hz}, 1 \mathrm{H}), 2.32-2.18(\mathrm{~m}$, $4 \mathrm{H}), 2.15(\mathrm{~d}, J=1.2 \mathrm{~Hz}, 3 \mathrm{H}), 2.10-2.00(\mathrm{~m}, 1 \mathrm{H}), 1.95-1.84(\mathrm{~m}, 2 \mathrm{H}), 1.67(\mathrm{~d}, J=1.0 \mathrm{~Hz}, 3 \mathrm{H}), 1.57$ (s, $3 \mathrm{H}), 1.25(\mathrm{dd}, J=15.4 \mathrm{~Hz}, 7.1 \mathrm{~Hz}, 2 \mathrm{H}), 0.93(\mathrm{~d}, J=6.8 \mathrm{~Hz}, 3 \mathrm{H}) ;{ }^{13} \mathrm{C}-\mathrm{NMR}\left(63 \mathrm{MHz}, \mathrm{CDCl}_{3}\right)$ Isomer $(2 Z, 6 E) \delta: 190.3$ (d), 163.1 (s), 138.1 (d), 130.7 (s), 128.5 (d), 125.9 (d), 124.4 (d), 36.8 (t), 35.9 (d),

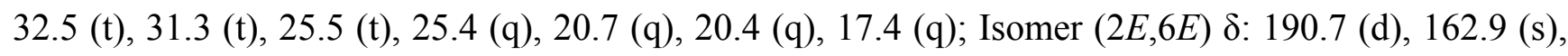
137.5 (d), 130.7 (s), 127.3 (d), 126.3 (d), 124.4 (d), 40.4 (t), 36.8 (t), 36.0 (d), 29.9 (t), $25.5(\mathrm{t}), 25.4$ (q), 20.5 (q), 17.4 (q), 17.2 (q); MS (70 eV) m/z (\%) Isomer (2Z,6E) $234[\mathrm{M}]^{+}(2), 69$ (100), 82 (82), 41 (81), 81 (77), 95 (69), 84 (61), 55 (57), 67 (53), 107 (34), 109 (32), 135 (22), 123 (21), 121 (20), 150 (16), 219 (6); Isomer (2E,6E) $234\left[\mathrm{M}^{+}(1), 69\right.$ (100), 84 (96), 81 (83), 82 (71), 41 (71), 95 (60), 55 (59), 67 (53), 107 (29), 109 (28), 150 (25), 151 (24), 135 (17), 121 (13). Anal. Calcd for: $\mathrm{C}_{16} \mathrm{H}_{26} \mathrm{O}: \mathrm{C}$, 81.99; H, 11.18. Found: C, 81.69; H, 11.15. 


\subsubsection{3,7,8,12-Tetramethyltrideca-2,6-dienal (20)}

Boiling point $120-124^{\circ} \mathrm{C} / 0.1$ Torr. Yield $36 \%$. Isolation by column chromatography gave a product with a yield of $83 \%$. IR (ATR) 2955, 2926, 2868, 2775, 1675, 1456, 1381, 1192, 1121, $852 \mathrm{~cm}^{-1}$; ${ }^{1} \mathrm{H}-\mathrm{NMR}$ $\left(250 \mathrm{MHz}, \mathrm{CDCl}_{3}\right)$ Isomer $(2 Z, 6 Z) \delta: 9.91(\mathrm{~d}, J=8.3 \mathrm{~Hz}, 1 \mathrm{H}), 5.87(\mathrm{~d}, J=8.3 \mathrm{~Hz}, 1 \mathrm{H}), 5.15-5.05(\mathrm{~m}$, $1 \mathrm{H}), 2.77-2.64(\mathrm{~m}, 2 \mathrm{H}), 2.59(\mathrm{t}, J=7.4 \mathrm{~Hz}, 2 \mathrm{H}), 2.30-2.17(\mathrm{~m}, 2 \mathrm{H}), 1.97(\mathrm{~s}, 3 \mathrm{H})$, $1.57-1.40(\mathrm{~m}, 1 \mathrm{H}), 1.54(\mathrm{~s}, 3 \mathrm{H}), 1.30-1.06(\mathrm{~m}, 6 \mathrm{H}), 0.93(\mathrm{~d}, J=6.9 \mathrm{~Hz}, 3 \mathrm{H}), 0.86-0.81(\mathrm{~m}, 6 \mathrm{H})$; Isomer $(2 Z, 6 E) \delta: 9.92(\mathrm{~d}, J=8.3 \mathrm{~Hz}, 1 \mathrm{H}), 5.87(\mathrm{~d}, J=8.3 \mathrm{~Hz}, 1 \mathrm{H}), 5.15-5.05(\mathrm{~m}, 1 \mathrm{H}), 2.59$ (t, $J=7.4 \mathrm{~Hz}, 2 \mathrm{H}), 2.30-2.17(\mathrm{~m}, 2 \mathrm{H}), 2.10-1.92(\mathrm{~m}, 2 \mathrm{H}), 1.97(\mathrm{~s}, 3 \mathrm{H}), 1.57-1.40(\mathrm{~m}, 1 \mathrm{H}), 1.50(\mathrm{~s}, 3 \mathrm{H})$, $1.30-1.06(\mathrm{~m}, 6 \mathrm{H}), 0.93(\mathrm{~d}, J=6.9 \mathrm{~Hz}, 3 \mathrm{H}), 0.86-0.81(\mathrm{~m}, 6 \mathrm{H})$; Isomer $(2 E, 6 Z) \delta: 9.98(\mathrm{~d}, J=8.1 \mathrm{~Hz}$, $1 \mathrm{H}), 5.85(\mathrm{~d}, J=8.1 \mathrm{~Hz}, 1 \mathrm{H}), 5.11-4.99(\mathrm{~m}, 1 \mathrm{H}), 2.77-2.64(\mathrm{~m}, 2 \mathrm{H}), 2.30-2.17(\mathrm{~m}, 3 \mathrm{H}), 1.97(\mathrm{~s}, 3 \mathrm{H})$, $1.57-1.40(\mathrm{~m}, 1 \mathrm{H}), 1.54(\mathrm{~s}, 3 \mathrm{H}), 1.30-1.06(\mathrm{~m}, 6 \mathrm{H}), 0.93(\mathrm{~d}, J=6.9 \mathrm{~Hz}, 3 \mathrm{H}), 0.86-0.81(\mathrm{~m}, 6 \mathrm{H})$; Isomer $(2 E, 6 E) \delta: 9.98(\mathrm{~d}, J=8.1 \mathrm{~Hz}, 1 \mathrm{H}), 5.85(\mathrm{~d}, J=8.1 \mathrm{~Hz}, 1 \mathrm{H}), 5.11-4.99(\mathrm{~m}, 1 \mathrm{H}), 2.30-2.17(\mathrm{~m}$, $3 \mathrm{H}), 2.10-1.92(\mathrm{~m}, 2 \mathrm{H}), 1.97(\mathrm{~s}, 3 \mathrm{H}), 1.57-1.40(\mathrm{~m}, 1 \mathrm{H}), 1.50(\mathrm{~s}, 3 \mathrm{H}), 1.30-1.06(\mathrm{~m}, 6 \mathrm{H}), 0.93(\mathrm{~d}$, $J=6.9 \mathrm{~Hz}, 3 \mathrm{H}), 0.86-0.81(\mathrm{~m}, 6 \mathrm{H}) ;{ }^{13} \mathrm{C}-\mathrm{NMR}\left(63 \mathrm{MHz}, \mathrm{CDCl}_{3}\right)$ Isomer $(2 Z, 6 Z) \delta: 190.6(\mathrm{~d}), 163.7$ $(\mathrm{s}), 141.3(\mathrm{~s}), 128.5(\mathrm{~d}), 122.5(\mathrm{~d}), 39.1(\mathrm{t}), 34.9(\mathrm{t}), 33.9$ (d), $32.9(\mathrm{t}), 27.8(\mathrm{~d}), 26.3(\mathrm{t}), 25.4(\mathrm{t}), 24.9$ (q), 22.6 (q), 22.5 (q), 19.2 (q), 17.9 (q); Isomer (2Z,6E) $\delta: 190.7$ (d), 163.9 (s), 141.5 (s), 128.5 (d), $121.2(\mathrm{~d}), 42.6(\mathrm{~d}), 39.0(\mathrm{t}), 35.0(\mathrm{t}), 32.5(\mathrm{t}), 27.8(\mathrm{~d}), 26.7(\mathrm{t}), 25.2(\mathrm{t}), 24.9(\mathrm{q}), 22.6(\mathrm{q}), 22.5(\mathrm{q})$, 19.5 (q), 12.5 (q); Isomer (2E,6Z) $\delta: 191.1$ (d), 163.7 (s), 140.7 (s), 127.3 (d), 122.8 (d), 40.9 (t), 39.1 $(\mathrm{t}), 34.8(\mathrm{t}), 33.9(\mathrm{~d}), 27.8(\mathrm{~d}), 25.4(\mathrm{t}), 25.0(\mathrm{t}), 22.6(\mathrm{q}), 22.5(\mathrm{q}), 19.2(\mathrm{q}), 17.9(\mathrm{q}), 17.4(\mathrm{q})$; Isomer $(2 E, 6 E) \delta: 191.1(\mathrm{~d}), 163.8(\mathrm{~s}), 140.8(\mathrm{~s}), 127.3(\mathrm{~d}), 122.6(\mathrm{~d}), 42.6(\mathrm{~d}), 40.5(\mathrm{t}), 38.9(\mathrm{t}), 35.0(\mathrm{t}), 27.8$ (d), 25.3 (t), 25.2 (t), 22.6 (q), 22.5 (q), 19.7 (q), 17.4 (q), 12.2 (q); MS (70 eV) m/z (\%) Isomer $(2 Z, 6 Z) 250[\mathrm{M}]^{+}(1), 69$ (100), 55 (87), 95 (70), 109 (58), 81 (47), 82 (47), 83 (47), 41 (43), 137 (43), 43 (41), 123 (20), 157 (12), 166 (11), 147 (11), 235 (3); Isomer (2Z,6E) $250[\mathrm{M}]^{+}$(4), 69 (100), 55 (62), 111 (36), 83 (36), 81 (35), 97 (35), 41 (28), 43 (25), 165 (17), 137 (15), 221 (4); Isomer (2E,6Z) $250[\mathrm{M}]^{+}(1), 69$ (100), 55 (84), 95 (64), 109 (51), 81 (46), 83 (46), 137 (39), 41 (39), 43 (37), 123 (15), 157 (12), 165 (11), 147 (10), 235 (3); Isomer (2E,6E) $250[\mathrm{M}]^{+}$(2), 69 (100), 55 (70), 111 (38), 97 (34), 83 (34), 81 (30), 57 (30), 41 (28), 43 (25), 137 (14), 165 (11), 221 (3). Anal. Calcd for: $\mathrm{C}_{17} \mathrm{H}_{30} \mathrm{O}: \mathrm{C}, 81.54 ; \mathrm{H}, 12.07$. Found: $\mathrm{C}, 81.96 ; \mathrm{H}, 12.15$.

\subsubsection{3,5,9-Trimethyldeca-2,8-dienal (21)}

B.P. 90-92 ${ }^{\circ} \mathrm{C} / 0.17$ Torr. Yield 54\%. IR (ATR) 2964, 2918, 2853, 2767, 1671, 1629, 1449, 1378, 1195, 1122, $867 \mathrm{~cm}^{-1}$; ${ }^{1} \mathrm{H}-\mathrm{NMR}\left(250 \mathrm{MHz}, \mathrm{CDCl}_{3}\right)$ Isomer $Z \delta: 9.91(\mathrm{~d}, J=8.3 \mathrm{~Hz}, 1 \mathrm{H}), 5.83(\mathrm{dd}$, $J=8.3 \mathrm{~Hz}, 1.2 \mathrm{~Hz}, 1 \mathrm{H}), 5.05(\mathrm{dqq}, J=7.1,1.3,1.3 \mathrm{~Hz}, 1 \mathrm{H}), 2.45(\mathrm{~d}, J=7.4 \mathrm{~Hz}, 2 \mathrm{H}), 2.01$ (dd, $J=16.0 \mathrm{~Hz}, 7.1 \mathrm{~Hz}, 3 \mathrm{H}), 1.92(\mathrm{~d}, J=1.2 \mathrm{~Hz}, 3 \mathrm{H}), 1.73(\mathrm{dd}, J=13.3 \mathrm{~Hz}, 6.8 \mathrm{~Hz}, 1 \mathrm{H}), 1.66(\mathrm{~d}, J=1.3 \mathrm{~Hz}$, $3 \mathrm{H}), 1.58(\mathrm{~s}, 3 \mathrm{H}), 1.43-1.12(\mathrm{~m}, 2 \mathrm{H}), 0.89(\mathrm{~d}, J=6.8 \mathrm{~Hz}, 3 \mathrm{H})$; Isomer $E \delta: 9.96(\mathrm{~d}, J=8.1 \mathrm{~Hz}, 1 \mathrm{H})$, $5.83(\mathrm{dd}, J=8.1 \mathrm{~Hz}, 1.2 \mathrm{~Hz}, 1 \mathrm{H}), 5.05(\mathrm{dqq}, J=7.1,1.3,1.3 \mathrm{~Hz}, 1 \mathrm{H}), 2.21$ (dd, $J=13.3 \mathrm{~Hz}$, $6.1 \mathrm{~Hz}, 1 \mathrm{H}), 2.10(\mathrm{~d}, J=1.2 \mathrm{~Hz}, 3 \mathrm{H}), 2.02-1.90(\mathrm{~m}, 3 \mathrm{H}), 1.72(\mathrm{dd}, J=13.4 \mathrm{~Hz}, 6.7 \mathrm{~Hz}, 1 \mathrm{H}), 1.66(\mathrm{~d}$, $J=1.3 \mathrm{~Hz}, 3 \mathrm{H}), 1.58(\mathrm{~s}, 3 \mathrm{H}), 1.40-1.05(\mathrm{~m}, 2 \mathrm{H}), 0.84(\mathrm{~d}, J=6.7 \mathrm{~Hz}, 3 \mathrm{H}) ;{ }^{13} \mathrm{C}-\mathrm{NMR}(63 \mathrm{MHz}$, $\mathrm{CDCl}_{3}$ ) Isomer $Z \delta: 190.8$ (d), 163.5 (s), 131.6 (s), 129.7 (d), 124.0 (d), 39.8 (t), 36.9 (t), 31.5 (d), 25.6 (q), 25.4 (t), 25.1 (q), 19.3 (q), 17.6 (q); Isomer $E \delta: 191.1$ (d), 163.2 (s), 131.5 (s), 128.6 (d), 124.1 
(d), 48.5 (t), 36.8 (t), 30.5 (d), $25.6(\mathrm{q}), 25.3$ (t), 19.3 (q), 17.6 (q), 17.3 (q); MS (70 eV) m/z (\%) Isomer Z 194 [M] $^{+}$(3), 109 (100), 95 (88), 69 (87), 41 (83), 55 (56), 111 (49), 151 (43), 67 (37), 81 (35), 84 (35), 43 (31), 123 (28), 138 (25), 179 (18); Isomer $E 194[\mathrm{M}]^{+}$(3), 69 (100), 41 (77), 95 (69), 109 (67), 55 (53), 111 (50), 67 (32), 84 (30), 179 (25), 81 (25), 107 (24), 123 (23), 137 (22), 151 (16). Anal. Calcd for: $\mathrm{C}_{13} \mathrm{H}_{22} \mathrm{O}$ : C, 80.35; H, 11.41. Found: C, 79.96; H, 11.49.

3.2.5. 3,6,10-Trimethylundeca-2,9-dienal (22)

B.P. 90-94 ${ }^{\circ} \mathrm{C} / 0.04$ Torr. Yield 46\%. IR (ATR) 2961, 2917, 2855, 2764, 1673, 1633, 1448, 1378, 1129, $839 \mathrm{~cm}^{-1} ;{ }^{1} \mathrm{H}-\mathrm{NMR}\left(250 \mathrm{MHz}, \mathrm{CDCl}_{3}\right)$ Isomer $Z \delta: 9.96(\mathrm{~d}, J=8.3 \mathrm{~Hz}, 1 \mathrm{H}), 5.83(\mathrm{dd}$, $J=8.3 \mathrm{~Hz}, 1.2 \mathrm{~Hz}, 1 \mathrm{H}), 5.08(\mathrm{t}, J=7.1 \mathrm{~Hz}, 1 \mathrm{H}), 2.56(\mathrm{t}, J=7.4 \mathrm{~Hz}, 2 \mathrm{H}), 2.02-1.92(\mathrm{~m}, 2 \mathrm{H}), 1.97$ (d, $J=1.2 \mathrm{~Hz}, 3 \mathrm{H}), 1.68(\mathrm{~s}, 3 \mathrm{H}), 1.60(\mathrm{~s}, 3 \mathrm{H}), 1.50-1.42(\mathrm{~m}, 1 \mathrm{H}), 1.40-1.32(\mathrm{~m}, 2 \mathrm{H}), 1.20-1.13(\mathrm{~m}, 2 \mathrm{H})$, $0.93(\mathrm{~d}, J=6.6 \mathrm{~Hz}, 3 \mathrm{H})$; Isomer $E \delta: 9.98(\mathrm{~d}, J=8.1 \mathrm{~Hz}, 1 \mathrm{H}), 5.85(\mathrm{dd}, J=8.1 \mathrm{~Hz}, 1.1 \mathrm{~Hz}, 1 \mathrm{H}), 5.08$ (t, $J=7.1 \mathrm{~Hz}, 1 \mathrm{H}), 2.22-2.16(\mathrm{~m}, 2 \mathrm{H}), 2.10(\mathrm{~d}, J=1.1 \mathrm{~Hz}, 3 \mathrm{H}), 1.98(\mathrm{dd}, J=14.5 \mathrm{~Hz}, 7.1 \mathrm{~Hz}, 2 \mathrm{H})$, $1.68(\mathrm{~s}, 3 \mathrm{H}), 1.60(\mathrm{~s}, 3 \mathrm{H}), 1.50-1.42(\mathrm{~m}, 1 \mathrm{H}), 1.40-1.32(\mathrm{~m}, 2 \mathrm{H}), 1.20-1.13(\mathrm{~m}, 2 \mathrm{H}), 0.95(\mathrm{~d}, J=6.5 \mathrm{~Hz}$, 3H); ${ }^{13} \mathrm{C}-\mathrm{NMR}\left(63 \mathrm{MHz}, \mathrm{CDCl}_{3}\right.$ ) Isomer $Z \delta$ : 190.8 (d), 165.7 (s), 131.3 (s), 127.9 (d), 124.4 (d), 36.6 $(\mathrm{t}), 36.2(\mathrm{t}) 32.4(\mathrm{~d}), 30.2(\mathrm{t}), 25.6(\mathrm{q}), 25.3(\mathrm{t}), 25.0(\mathrm{q}), 19.3(\mathrm{q}), 17,5(\mathrm{q})$; Isomer $E \delta: 190.7(\mathrm{~d}), 165.3$ $(\mathrm{s}), 130.9(\mathrm{~s}), 127.9(\mathrm{~d}), 124.8(\mathrm{~d}), 36.7(\mathrm{t}), 36.3(\mathrm{t}), 36.0(\mathrm{t}), 32.7(\mathrm{~d}), 25.6(\mathrm{q}), 25.4(\mathrm{t}), 19.2(\mathrm{q}), 17.5$ (q), 17.5 (q); MS (70 eV) m/z (\%) Isomer Z: 208 [M] $]^{+}$(4), 69 (100), 97 (90), 41 (81), 84 (67), 109 (64), 95 (57), 55 (47), 82 (35), 67 (34), 123 (27), 193 (21); Isomer E: 208 [M] (8), 69 (100), 97 (97), 41 (77), 84 (52), 55 (49), 109 (48), 95 (44), 67 (30), 81 (28), 123 (26), 193 (13). Anal. Calcd for: $\mathrm{C}_{14} \mathrm{H}_{24} \mathrm{O}: \mathrm{C}, 80.71 ; \mathrm{H}, 11.61$. Found: C, 80.62; H, 11.71 .

3.2.6. 3,4,6,10-Tetramethylundeca-2,9-dienal (23)

Boiling point $115-117{ }^{\circ} \mathrm{C} / 0.16$ Torr. Yield 67\%. IR (ATR) 2964, 2916, 2873, 2851, 2756, 1672, 1632, 1455, 1378, 1198, 1135, $858 \mathrm{~cm}^{-1}$; ${ }^{1} \mathrm{H}-\mathrm{NMR}\left(250 \mathrm{MHz}, \mathrm{CDCl}_{3}\right) Z$ Isomers $\delta: 10.06(\mathrm{~d}, J=8.3 \mathrm{~Hz}$, $1 \mathrm{H}), 5.83(\mathrm{~d}, J=8.3 \mathrm{~Hz}, 1 \mathrm{H}), 5.13-5.00(\mathrm{~m}, 1 \mathrm{H}), 3.63-3.50(\mathrm{~m}, 1 \mathrm{H}), 2.04-1.89(\mathrm{~m}, 2 \mathrm{H})$, Racemate 1 and 2: 1.87 and $1.85(\mathrm{~d}, J=1.2 \mathrm{~Hz}, 3 \mathrm{H}), 1.67(\mathrm{~s}, 3 \mathrm{H}), 1.59(\mathrm{~s}, 3 \mathrm{H}), 1.55-1.22(\mathrm{~m}, 5 \mathrm{H})$, Racemate 1 and 2: 1.12 and $1.07(\mathrm{~d}, J=6.7 \mathrm{~Hz}, 3 \mathrm{H}), 0.91-0.86(\mathrm{~m}, 3 \mathrm{H}) ; E$ Isomers $\delta: 10.01$ (d, $J=8.0 \mathrm{~Hz}, 1 \mathrm{H}), 5.89$ (dd, $J=8.0 \mathrm{~Hz}, 1.2 \mathrm{~Hz}, 1 \mathrm{H}), 5.06(\mathrm{dqq}, J=7.0,1.2,1.2 \mathrm{~Hz}, 1 \mathrm{H}), 2.38(\mathrm{~m}, 1 \mathrm{H})$, Raemate 4: $2.12(\mathrm{~d}$, $J=1.2 \mathrm{~Hz}, 3 \mathrm{H})$, Racemate 3: $2.09(\mathrm{~d}, J=1.2 \mathrm{~Hz}, 3 \mathrm{H}), 2.03-1.90(\mathrm{~m}, 2 \mathrm{H}), 1.67(\mathrm{~d}, J=1.2 \mathrm{~Hz}, 3 \mathrm{H})$, $1.59(\mathrm{~d}, J=1.2 \mathrm{~Hz}, 3 \mathrm{H}), 1.52-1.15(\mathrm{~m}, 5 \mathrm{H})$, Racemate 3: $1.07(\mathrm{~d}, J=6.8 \mathrm{~Hz}, 3 \mathrm{H})$, Racemate 4: 1.85 $(\mathrm{d}, J=6.8 \mathrm{~Hz}, 3 \mathrm{H}), 0.87(\mathrm{~d}, J=6.3 \mathrm{~Hz}, 3 \mathrm{H}) ;{ }^{13} \mathrm{C}-\mathrm{NMR}\left(63 \mathrm{MHz}, \mathrm{CDCl}_{3}\right) Z$ Racemate 1 and $2 \delta$ : 189.9 (d), 189.8 (d), 168.9 (s), 168.4 (s), 131.3 (s), 131.2 (s), 129.1 (d), 128.4 (d), 124.6 (d), 124.4 (d), $42.3(\mathrm{t}), 41.8(\mathrm{t}), 37.5(\mathrm{t}), 36.7(\mathrm{t}), 32.3(\mathrm{~d}), 30.2(\mathrm{~d}), 30.2(\mathrm{~d}), 25.6(\mathrm{q}), 25.3(\mathrm{t}), 19.8(\mathrm{q}), 19.4(\mathrm{q}), 19.2$

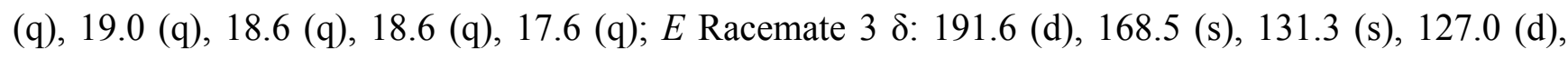
124.5 (d), 41.9 (t), 41.2 (d), $37.3(\mathrm{t}), 30.1$ (d), 25.6 (q), 25.3 (t), 19.7 (q), 19.5 (q), 17.6 (q), 13.8 (q); $E$

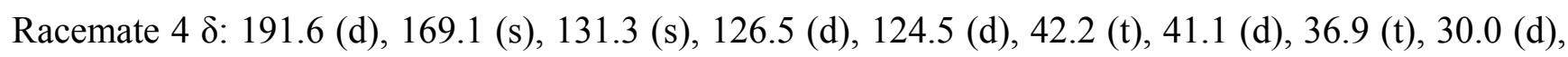
25.6 (q), 25.2 (t), 19.6 (q), 18.7 (q), 17.6 (q), 14.6 (q); MS (70 eV) m/z (\%) Racemate 1 (Z) $222[\mathrm{M}]^{+}$ (2), 69 (100), 41 (77), 109 (70), 111 (60), 55 (47), 95 (44), 85 (41), 83 (40), 98 (36), 43 (33), 149 (24), 152 (30), 123 (19), 166 (10), 207 (6); Racemate $2(Z) 222[\mathrm{M}]^{+}$(3), 69 (100), 41 (87), 111 (77), 109 (70), 55 (50), 98 (47), 95 (47), 83 (41), 152 (40), 43 (33), 67 (32), 149 (26), 123 (19), 166 (12), 207 
(7); Racemate 3 (E) $222[\mathrm{M}]^{+}$(3), 69 (100), 111 (91), 41 (77), 109 (60), 98 (43), 55 (42), 95 (37), 83 (32), 152 (29), 81 (28), 67 (27), 43 (21), 149 (19), 123 (14), 207 (6); Racemate 4 (E) $222[\mathrm{M}]^{+}$(4), 69 (100), 111 (78), 41 (77), 109 (60), 98 (39), 55 (39), 95 (34), 83 (30), 81 (27), 67 (26), 152 (24), 43 (21), 149 (20), 123 (14), 166 (6). Anal. Calcd for: $\mathrm{C}_{15} \mathrm{H}_{26} \mathrm{O}$ : C, 81.02; H, 11.79. Found: C, 80.94; H, 11.65.

\subsection{Sodium Borohydride Reduction of Aldehydes Structurally Related to Farnesol (24-29)}

A total of $0.11 \mathrm{~g}(3 \mathrm{mmol})$ of sodium borohydride was added portion-wise to the stirred solution of $5.5 \mathrm{mmol}$ of appropriate aldehyde (18-23) dissolved in $10 \mathrm{~mL}$ of isopropanol. After addition, the reaction mixture was stirred for $24 \mathrm{~h}$. Next isopropanol was removed by evaporation and the residue was transferred to the separatory funnel, after which $20 \mathrm{~mL}$ of water and $30 \mathrm{~mL}$ of hexane was added. After separation of the organic layer, the water layer was extracted with hexane $(2 \times 20 \mathrm{~mL})$. The combined extracts were washed with brine and dried over anhydrous magnesium sulphate. The product was purified by column chromatography on silica gel using hexane:ethyl acetate (97:3), or distilled (see below).

\subsubsection{3,7,8,12-Tetramethyltrideca-2,6,11-trien-1-ol (24)}

Yield 87\%. IR (ATR) 3306, 2962, 2919, 2856, 1667, 1448, 1376, 1001, $829 \mathrm{~cm}^{-1} .{ }^{1} \mathrm{H}-\mathrm{NMR}$ $\left(250 \mathrm{MHz}, \mathrm{CDCl}_{3}\right)$ Isomer $(2 Z, 6 Z)$ and $(2 Z, 6 E) \delta: 5.58-5.39(\mathrm{~m}, 1 \mathrm{H}), 5.15-5.00(\mathrm{~m}, 2 \mathrm{H}), 4.11(\mathrm{~d}$, $J=7.1 \mathrm{~Hz}, 2 \mathrm{H}), 2.18-1.98(\mathrm{~m}, 5 \mathrm{H}), 1.85(\mathrm{dd}, J=14.7 \mathrm{~Hz}, 7.2 \mathrm{~Hz}, 2 \mathrm{H}), 1.75(\mathrm{~d}, J=1.3 \mathrm{~Hz}, 3 \mathrm{H}), 1.67$ $(\mathrm{d}, J=0.9 \mathrm{~Hz}, 3 \mathrm{H}), 1.58(\mathrm{~s}, 3 \mathrm{H}), 1.51(\mathrm{~d}, J=1.0 \mathrm{~Hz}, 3 \mathrm{H}), 1.40-1.15(\mathrm{~m}, 2 \mathrm{H}), 0.96(\mathrm{~d}, J=6.9 \mathrm{~Hz}$, $3 \mathrm{H})$; Isomer $(2 E, 6 Z)$ and $(2 E, 6 E) \delta: 5.45-5.37(\mathrm{~m}, 1 \mathrm{H}), 5.15-5.05(\mathrm{~m}, 2 \mathrm{H}), 4.14(\mathrm{~d}, J=6.9 \mathrm{~Hz}, 2 \mathrm{H})$, 2.16-2.00 (m, 5H), $1.85(\mathrm{dd}, J=14.7 \mathrm{~Hz}, 7.1 \mathrm{~Hz}, 2 \mathrm{H}), 1.68(\mathrm{~s}, 6 \mathrm{H}), 1.58(\mathrm{~s}, 3 \mathrm{H}), 1.51(\mathrm{~d}, J=0.9 \mathrm{~Hz}, 3 \mathrm{H})$, $1.42-1.21(\mathrm{~m}, 2 \mathrm{H}), 0.96(\mathrm{~d}, J=6.9 \mathrm{~Hz}, 3 \mathrm{H}) ;{ }^{13} \mathrm{C}-\mathrm{NMR}\left(63 \mathrm{MHz}, \mathrm{CDCl}_{3}\right)$ Isomer $(2 Z, 6 Z) \delta: 140.0(\mathrm{~s})$, $139.6(\mathrm{~s}), 131.2(\mathrm{~s}), 124.7$ (d), $124.4(\mathrm{~d}), 124.4(\mathrm{~d}), 58.9(\mathrm{t}), 34.9(\mathrm{t}), 33.5(\mathrm{~d}), 32.3(\mathrm{t}), 26.2(\mathrm{t}), 25.7(\mathrm{t})$, 25.6 (q), 23.4 (q), 19.2 (q), 17.9 (q), 17.6 (q); Isomer (2Z,6E) $\delta: 139.8$ (s), 139.8 (s), 131.0 (s), 124.8 $(\mathrm{d}), 124.3(\mathrm{~d}), 123.0(\mathrm{~d}), 58.9(\mathrm{t}), 42.3(\mathrm{~d}), 35.0(\mathrm{t}), 32.0(\mathrm{t}), 26.3(\mathrm{t}), 26.1(\mathrm{t}), 25.6(\mathrm{q}), 23.4(\mathrm{q}), 19.6$ (q), $17.6(\mathrm{q}), 12.2(\mathrm{q})$; Isomer $(2 E, 6 Z) \delta: 139.6(\mathrm{~s}), 139.4(\mathrm{~s}), 131.1(\mathrm{~s}), 124.8(\mathrm{~d}), 124.4$ (d), $123.4(\mathrm{~d})$, $59.2(\mathrm{t}), 39.9(\mathrm{t}), 34.9(\mathrm{t}), 33.5(\mathrm{~d}), 26.2(\mathrm{t}), 25.7(\mathrm{t}), 25.6(\mathrm{q}), 19.2(\mathrm{q}), 17.9(\mathrm{q}), 17.6(\mathrm{q}), 16.2(\mathrm{q}) ;$ Isomer $(2 E, 6 E) \delta$ : $139.6(\mathrm{~s}), 139.4(\mathrm{~s}), 131.0(\mathrm{~s}), 124.8(\mathrm{~d}), 123.4(\mathrm{~d}), 123.3(\mathrm{~d}), 59.2(\mathrm{t}), 42.3(\mathrm{~d}), 39.5$ $(\mathrm{t}), 35.0(\mathrm{t}), 26.1(\mathrm{t}), 26.0(\mathrm{t}), 25.6(\mathrm{q}), 19.7(\mathrm{q}), 17.6(\mathrm{q}), 16.2(\mathrm{q}), 12.2(\mathrm{q}) ; \mathrm{MS}(70 \mathrm{eV}) \mathrm{m} / \mathrm{z}(\%) 250$ $[\mathrm{M}]^{+}(1), 232\left([\mathrm{M}]^{+}-18,2\right), 82$ (100), 69 (69), 109 (40), 95 (33), 81 (27), 41 (26), 55 (25), 83 (25), 121 (16), 168 (4), 217 (2). Anal. Calcd for: $\mathrm{C}_{17} \mathrm{H}_{30} \mathrm{O}: \mathrm{C}, 81.54 ; \mathrm{H}, 12.07$. Found: C, 81.46; H, 12.02.

\subsection{2. (6E)-3,8,12-Trimethyltrideca-2,6,11-trien-1-ol (25)}

Yield 74\%. IR (ATR): 3340, 2965, 2916, 2855, 1670, 1450, 1377, 997, 968, 911, $733 \mathrm{~cm}^{-1} .{ }^{1} \mathrm{H}-\mathrm{NMR}$ $\left(250 \mathrm{MHz}, \mathrm{CDCl}_{3}\right)$ Isomer $(2 \mathrm{Z}, 6 E) \delta: 5.47-5.38(\mathrm{~m}, 1 \mathrm{H}), 5.35-5.20(\mathrm{~m}, 2 \mathrm{H}), 5.12-5.04(\mathrm{~m}, 1 \mathrm{H}), 4.10$ $(\mathrm{d}, J=7.2 \mathrm{~Hz}, 2 \mathrm{H}), 2.18-2.00(\mathrm{~m}, 5 \mathrm{H}), 1.92(\mathrm{dd}, J=15.3 \mathrm{~Hz}, 7.3 \mathrm{~Hz}, 2 \mathrm{H}), 1.73(\mathrm{~d}, J=1.0 \mathrm{~Hz}, 3 \mathrm{H})$, $1.67(\mathrm{~s}, 3 \mathrm{H}), 1.58(\mathrm{~s}, 3 \mathrm{H}), 1.26(\mathrm{dd}, J=15.4 \mathrm{~Hz}, 7.3 \mathrm{~Hz}, 2 \mathrm{H}), 0.94(\mathrm{~d}, J=6.7 \mathrm{~Hz}, 3 \mathrm{H})$; Isomer $(2 E, 6 E)$ $\delta: ~ 5.44-5.38(\mathrm{~m}, 1 \mathrm{H}), 5.34-5.18(\mathrm{~m}, 2 \mathrm{H}), 5.12-5.04(\mathrm{~m}, 1 \mathrm{H}), 4.12(\mathrm{~d}, J=7.1 \mathrm{~Hz}, 2 \mathrm{H}), 2.15-2.00(\mathrm{~m}$, 5H), $1.92(\mathrm{dd}, J=15.3 \mathrm{~Hz}, 7.2 \mathrm{~Hz}, 2 \mathrm{H}), 1.67$ (s, 3H), 1.66 (d, $J=0.9 \mathrm{~Hz}, 3 \mathrm{H}), 1.58$ (s, 3H), 1.25 (dd, 
$J=14.8 \mathrm{~Hz}, 7.2 \mathrm{~Hz}, 2 \mathrm{H}), 0.94(\mathrm{~d}, J=6.7 \mathrm{~Hz}, 3 \mathrm{H}) ;{ }^{13} \mathrm{C}-\mathrm{NMR}\left(63 \mathrm{MHz}, \mathrm{CDCl}_{3}\right)$ Isomer $(2 Z, 6 E) \delta$ : $138.7(\mathrm{~s}), 136.7$ (d), 130.8 (s), 127.5 (d), 124.6 (d), 124.5 (d), $58.6(\mathrm{t}), 37.0(\mathrm{t}), 36.1$ (d), $32.0(\mathrm{t}), 31.0$ $(\mathrm{t}), 25.6(\mathrm{t}), 25.5(\mathrm{q}), 23.2(\mathrm{q}), 20.6(\mathrm{q}), 17.4(\mathrm{q})$; Isomer $(2 E, 6 E) \delta: 138.5(\mathrm{~s}), 136.4(\mathrm{~d}), 130.8(\mathrm{~s})$, $127.7(\mathrm{~d}), 124.6(\mathrm{~d}), 123.6(\mathrm{~d}), 58.8(\mathrm{t}), 39.5(\mathrm{t}), 37.0(\mathrm{t}), 36.1(\mathrm{~d}), 30.7(\mathrm{t}), 25.6(\mathrm{t}), 25.5(\mathrm{q}), 20.7(\mathrm{q})$, 17.4 (q), 16.0 (q); MS (70 eV) m/z (\%) Isomer (2Z,6E) $236[\mathrm{M}]^{+}(0), 218$ ([M] $\left.]^{+}-18,1\right), 69(100), 41$ (51), 82 (47), 81 (45), 55 (36), 95 (34), 67 (30), 93 (26), 107 (21), 109 (17); Isomer (2E,6E) 236 [M] $]^{+}$ (0), 218 ([M] $\left.]^{+}-18,1\right), 69$ (100), 82 (66), 41 (59), 81 (58), 95 (50), 55 (42), 67 (38), 93 (27), 107 (26), 109 (24), 135 (14). Anal. Calcd for: $\mathrm{C}_{16} \mathrm{H}_{28} \mathrm{O}$ : C, 81.29; H, 11.94. Found: C, 81.12; H, 11.89.

\subsubsection{3,7,8,12-Tetramethyltrideca-2,6-dien-1-ol (26)}

Yield 95\%. IR (ATR) 3309, 2955, 2925, 2869, 1667, 1456, 1380, 1368, 1092, 1002, 955, $836 \mathrm{~cm}^{-1}$. ${ }^{1} \mathrm{H}-\mathrm{NMR}\left(250 \mathrm{MHz}, \mathrm{CDCl}_{3}\right)$ Isomer $(2 Z, 6 Z)$ and $(2 Z, 6 E) \delta: 5.48-5.38(\mathrm{~m}, 1 \mathrm{H}), 5.14-5.04(\mathrm{~m}, 1 \mathrm{H})$, $4.11(\mathrm{~d}, J=7.1 \mathrm{~Hz}, 2 \mathrm{H}), 2.13-2.00(\mathrm{~m}, 5 \mathrm{H}), 1.75(\mathrm{~d}, J=1.0 \mathrm{~Hz}, 3 \mathrm{H}), 1.59-1.46(\mathrm{~m}, 1 \mathrm{H}), 1.51(\mathrm{~d}$, $J=1.2 \mathrm{~Hz}, 3 \mathrm{H}), 1.35-1.10(\mathrm{~m}, 6 \mathrm{H}), 0.95(\mathrm{~d}, J=6.9 \mathrm{~Hz}, 3 \mathrm{H}), 0.86(\mathrm{~d}, J=6.6 \mathrm{~Hz}, 6 \mathrm{H})$; Isomer $(2 E, 6 Z)$ and $(2 E, 6 E) \delta: 5.46-5.38(\mathrm{~m}, 1 \mathrm{H}), 5.10(\mathrm{t}, J=5.7 \mathrm{~Hz}, 1 \mathrm{H}), 4.15(\mathrm{~d}, J=7.0 \mathrm{~Hz}, 2 \mathrm{H}), 2.18-1.97(\mathrm{~m}$, $5 \mathrm{H}), 1.68(\mathrm{~d}, J=0.6 \mathrm{~Hz}, 3 \mathrm{H}), 1.62-1.44(\mathrm{~m}, 1 \mathrm{H}), 1.50(\mathrm{~d}, J=1.2 \mathrm{~Hz}, 3 \mathrm{H}), 1.33-1.05(\mathrm{~m}, 6 \mathrm{H}), 0.95(\mathrm{~d}$, $J=6.9 \mathrm{~Hz}, 3 \mathrm{H}), 0.85(\mathrm{~d}, J=6.6 \mathrm{~Hz}, 3 \mathrm{H}), 0.84(\mathrm{~d}, J=6.6 \mathrm{~Hz}, 3 \mathrm{H}) ;{ }^{13} \mathrm{C}-\mathrm{NMR}\left(63 \mathrm{MHz}, \mathrm{CDCl}_{3}\right)$ Isomer $(2 Z, 6 Z) \delta: 140.3(\mathrm{~s}), 139.7(\mathrm{~s}), 124.5(\mathrm{~d}), 124.2(\mathrm{~d}), 58.9(\mathrm{t}), 39.2(\mathrm{t}), 35.0(\mathrm{t}), 33.9(\mathrm{~d}), 32.3(\mathrm{t})$, $27.9(\mathrm{~d}), 25.8(\mathrm{t}), 25.5(\mathrm{t}), 23.4(\mathrm{q}), 22.7(\mathrm{q}), 22.6(\mathrm{q}), 19.4(\mathrm{q}), 17.9(\mathrm{q})$; Isomer $(2 Z, 6 E)$ ): $140.2(\mathrm{~s})$, $139.9(\mathrm{~s}), 124.3(\mathrm{~d}), 122.7(\mathrm{~d}), 59.0(\mathrm{t}), 42.7(\mathrm{~d}), 39.1(\mathrm{t}), 35.1(\mathrm{t}), 32.0(\mathrm{t}), 27.9(\mathrm{~d}), 26.3(\mathrm{t}), 25.3(\mathrm{t})$, 23.4 (q), 22.7 (q), 22.6 (q), 19.7 (q), 12.2 (q); Isomer (2E,6Z) $\delta: 139.7$ (s), 139.6 (s), 124.2 (d), 123.3 $(\mathrm{d}), 62.3(\mathrm{t}), 39.9(\mathrm{t}), 39.2(\mathrm{t}), 35.0(\mathrm{t}), 33.9(\mathrm{~d}), 27.9(\mathrm{~d}), 25.6(\mathrm{t}), 25.5(\mathrm{t}), 22.6(\mathrm{q}), 22.6(\mathrm{q}), 19.4(\mathrm{q})$, 17.9 (q), 16.2 (q); Isomer (2E,6E) $\delta: 149.7$ (s), 139.6 (s), 123.3 (d), 123.0 (d), 62.3 (t), 42.7 (d), 39.6 $(\mathrm{t}), 39.1(\mathrm{t}), 35.1(\mathrm{t}), 27.9(\mathrm{~d}), 26.1(\mathrm{t}), 25.2(\mathrm{t}), 22.7(\mathrm{q}), 22.6(\mathrm{q}), 19.8(\mathrm{q}), 16.2(\mathrm{q}), 12.1(\mathrm{q}) ; \operatorname{MS}(70$ eV) $m / z(\%)$ Isomer (2Z,6Z) $252[\mathrm{M}]^{+}$(4), 69 (100), 55 (74), 111 (44), 83 (41), 84 (39), 97 (37), 57 (33), 93 (32), 41 (30), 43 (28), 121 (24), 221 (4); Isomer (2Z,6E) $252[\mathrm{M}]^{+}$(3), 69 (100), 55 (67), 111 (54), 83 (36), 97 (35), 57 (34), 41 (28), 43 (25), 81 (25), 93 (24), 121 (15), 221 (4); Isomer (2E,6Z) 252 $[\mathrm{M}]^{+}(3), 69$ (100), 55 (75), $111(50), 83$ (41), 97 (40), 57 (36), 84 (33), 93 (31), 41 (31), 43 (28), 121 (22), 221 (3); Isomer (2E,6E) $252\left[\mathrm{M}^{+}\right.$(2), 69 (100), 55 (61), 111 (53), 83 (34), 97 (32), 57 (31), 41 (24), 43 (21), 81 (21), 93 (18), 121 (11), 221 (3). Anal. Calcd for: $\mathrm{C}_{17} \mathrm{H}_{32} \mathrm{O}: \mathrm{C}, 80.89$; H, 12.78. Found: $\mathrm{C}, 81.03 ; \mathrm{H}, 12.85$.

\subsubsection{3,5,9-Trimethyldeca-2,8-dien-1-ol (27)}

Boiling point $94-96{ }^{\circ} \mathrm{C} / 0.5$ Torr. Yield 69\%. IR (ATR) 3312, 2964, 2913, 2872, 1668, 1449, 1377 , 1063, 996, $889 \mathrm{~cm}^{-1} ;{ }^{1} \mathrm{H}-\mathrm{NMR}\left(250 \mathrm{MHz}, \mathrm{CDCl}_{3}\right)$ Isomer $Z: \delta: 5.42-5.34(\mathrm{~m}, 1 \mathrm{H}), 5.14-5.04(\mathrm{~m}, 1 \mathrm{H})$, $4.15(\mathrm{~d}, J=6.9 \mathrm{~Hz}, 2 \mathrm{H}), 2.08-1.97(\mathrm{~m}, 4 \mathrm{H}), 1.70(\mathrm{~d}, J=1.2 \mathrm{~Hz}, 3 \mathrm{H}), 1.68(\mathrm{~d}, J=1.1 \mathrm{~Hz}, 3 \mathrm{H}), 1.65-1.52$ $(\mathrm{m}, 1 \mathrm{H}), 1.60(\mathrm{~s}, 3 \mathrm{H}), 1.40-1.24(\mathrm{~m}, 1 \mathrm{H}), 1.18-1.04(\mathrm{~m}, 1 \mathrm{H}), 0.82(\mathrm{~d}, J=6.6 \mathrm{~Hz}, 3 \mathrm{H})$; Isomer $E$ : $\delta$ : 5.52-5.43 (m, 1H), 5.14-5.04 (m, 1H), $4.11(\mathrm{~d}, J=7.1 \mathrm{~Hz}, 2 \mathrm{H}), 2.09-1.99(\mathrm{~m}, 2 \mathrm{H}), 1.92$ (dd, $J=13.1 \mathrm{~Hz}, 8.3 \mathrm{~Hz}, 1 \mathrm{H}), 1.78(\mathrm{dd}, J=13.1 \mathrm{~Hz}, 8.3 \mathrm{~Hz}, 1 \mathrm{H}), 1.68(\mathrm{~d}, J=1.1 \mathrm{~Hz}, 3 \mathrm{H}), 1.65-1.52$ (m, $1 \mathrm{H}), 1.64(\mathrm{~s}, 3 \mathrm{H}), 1.60(\mathrm{~s}, 3 \mathrm{H}), 1.40-1.24(\mathrm{~m}, 1 \mathrm{H}), 1.18-1.04(\mathrm{~m}, 1 \mathrm{H}), 0.83(\mathrm{~d}, J=6.5 \mathrm{~Hz}, 3 \mathrm{H})$; ${ }^{13} \mathrm{C}-\mathrm{NMR}\left(63 \mathrm{MHz}, \mathrm{CDCl}_{3}\right.$ ) Isomer Z: $\delta: 137.7$ (s), 130.8 (s), 125.5 (d), 125.0 (d), 58.6 (t), 39.3 (t), 
$36.8(\mathrm{t}), 30.6(\mathrm{~d}), 25.4(\mathrm{q}), 25.3(\mathrm{t}), 23.4(\mathrm{q}), 19.1(\mathrm{q}), 17.3(\mathrm{q})$; Isomer $E$ : $\delta: 137.4(\mathrm{~s}), 130.7(\mathrm{~s}), 124.6$ (d), $124.5(\mathrm{~d}), 58.7(\mathrm{t}), 47.4(\mathrm{t}), 36.7(\mathrm{t}), 30.0(\mathrm{~d}), 25.4(\mathrm{q}), 25.3(\mathrm{t}), 19.1(\mathrm{q}), 17.3(\mathrm{q}), 15.7(\mathrm{q}) ; \mathrm{MS}$ $(70 \mathrm{eV}) \mathrm{m} / z(\%)$ Isomer Z: $196[\mathrm{M}]^{+}$(2), 69 (100), 109 (66), 41 (63), 95 (62), 55 (46), 111 (42), 82 (42), 67 (40), 107 (36), 81 (28), 93 (25), 163 (15); Isomer $E$ : $196\left[\mathrm{M}^{+}\right.$(2), 69 (100), 41 (65), 95 (64), 109 (63), 82 (55), 55 (41), 67 (38), 81 (26), 107 (23), 111 (20). Anal. Calcd for: $\mathrm{C}_{13} \mathrm{H}_{24} \mathrm{O}: \mathrm{C}, 79.53$; H, 12.32. Found: C, 79.44; H, 12.36 .

\subsubsection{3,6,10-Trimethylundeca-2,9-dien-1-ol (28)}

Yield 97\%. IR (ATR) 3319, 2963, 2915, 2855, 1669, 1452, 1377, 1114, 1075, 998, $954 \mathrm{~cm}^{-1}$; ${ }^{1} \mathrm{H}-\mathrm{NMR}\left(700 \mathrm{MHz}, \mathrm{CDCl}_{3}\right.$ ) Isomer $Z: \delta: 5.39(\mathrm{t}, J=6.9 \mathrm{~Hz}, 1 \mathrm{H}), 5.09$ (t, $\left.J=6.9 \mathrm{~Hz}, 1 \mathrm{H}\right), 4.12(\mathrm{~d}$, $J=6.9 \mathrm{~Hz}, 1 \mathrm{H}), 2.10-2.01(\mathrm{~m}, 2 \mathrm{H}), 1.99(\mathrm{dd}, J=14.8,6.9 \mathrm{~Hz}, 1 \mathrm{H}), 1.96-1.89(\mathrm{~m}, 1 \mathrm{H}), 1.73(\mathrm{~s}, 3 \mathrm{H})$, $1.68(\mathrm{~s}, 3 \mathrm{H}), 1.60(\mathrm{~s}, 3 \mathrm{H}), 1.40(\mathrm{dd}, J=12.3,6.5 \mathrm{~Hz}, 1 \mathrm{H}), 1.38-1.35(\mathrm{~m}, 1 \mathrm{H}), 1.34-1.30(\mathrm{~m}, 1 \mathrm{H})$, $1.21-1.18(\mathrm{~m}, 1 \mathrm{H}), 1.17-1.12(\mathrm{~m}, 1 \mathrm{H}), 0.89(\mathrm{~d}, J=6.5 \mathrm{~Hz}, 3 \mathrm{H})$; Isomer $E: \delta: 5.43-5.39(\mathrm{~m}, 1 \mathrm{H})$, 5.12-5.08 (m, 1H), 4.14 (s. 2H), 2.07-2.02 (m, 1H), 2.01-1.96 (m, 2H), $1.93(\mathrm{dd}, J=14.5,7.1 \mathrm{~Hz}$, $1 \mathrm{H}), 1.68(\mathrm{~d}, J=1.2 \mathrm{~Hz}, 3 \mathrm{H}), 1.67(\mathrm{~s}, 3 \mathrm{H}), 1.60(\mathrm{~s}, 3 \mathrm{H}), 1.46-1.41(\mathrm{~m}, 1 \mathrm{H}), 1.39(\mathrm{dd}, J=12.8,6.6 \mathrm{~Hz}$, $1 \mathrm{H}), 1.36-1.31(\mathrm{~m}, 1 \mathrm{H}), 1.26-1.20(\mathrm{~m}, 1 \mathrm{H}), 1.18-1.12(\mathrm{~m}, 1 \mathrm{H}), 0.88(\mathrm{~d}, J=6.6 \mathrm{~Hz}, 3 \mathrm{H}) ;{ }^{13} \mathrm{C}-\mathrm{NMR}$ $\left(176 \mathrm{MHz}, \mathrm{CDCl}_{3}\right)$ Isomer Z: $\delta: 140.4(\mathrm{~s}), 131.0(\mathrm{~s}), 124.7(\mathrm{~d}), 123.8(\mathrm{~d}), 58.8(\mathrm{t}), 36.8(\mathrm{t}), 35.6(\mathrm{t})$, $32.4(\mathrm{~d}), 29.4(\mathrm{t}), 25.6(\mathrm{q}), 25.4(\mathrm{t}), 23.4(\mathrm{q}), 19.4(\mathrm{q}), 17.5(\mathrm{q})$; Isomer $E$ : $\delta: 140.0(\mathrm{~s}), 130.9(\mathrm{~s}), 124.8$ $(\mathrm{d}), 123.0(\mathrm{~d}), 59.2(\mathrm{t}), 37.0(\mathrm{t}), 36.9(\mathrm{t}), 34.9(\mathrm{t}), 32.1(\mathrm{~d}), 25.6(\mathrm{q}), 25.4(\mathrm{t}), 19.4(\mathrm{q}), 17.5(\mathrm{q}), 16.1(\mathrm{q})$; MS (70 eV) m/z (\%) Isomer Z: $210[\mathrm{M}]^{+}$(3), 69 (100), 109 (65), 81 (59), 41 (59), 55 (44), 82 (43), 107 (37), 67 (35), 84 (33), 177 (12); Isomer $E$ : $210[\mathrm{M}]^{+}$(1), 69 (100), 109 (77), 81 (67), 41 (58), 82 (40), 55 (40), 67 (32), 95 (27), 71 (25), 107 (22). Anal. Calcd for: $\mathrm{C}_{14} \mathrm{H}_{26} \mathrm{O}: \mathrm{C}, 79.94 ; \mathrm{H}, 12.46$. Found: C, $80.11 ; \mathrm{H}, 12.53$.

\subsubsection{3,4,6,10-Tetramethylundeca-2,9-dien-1-ol (29)}

Yield 49\%. IR (ATR) 3322, 2963, 2914, 2872, 1664, 1455, 1377, 1161, 1129, 1028, 998, 953, $818 \mathrm{~cm}^{-1} ;{ }^{1} \mathrm{H}-\mathrm{NMR}\left(250 \mathrm{MHz}, \mathrm{CDCl}_{3}\right) Z$ Isomers $\delta: 5.35(\mathrm{td}, J=6.9 \mathrm{~Hz}, 1.3 \mathrm{~Hz}, 1 \mathrm{H}), 5.12-5.02(\mathrm{~m}$, $1 \mathrm{H}), 4.18-4.11(\mathrm{~m}, 2 \mathrm{H}), 2.75(\mathrm{dd}, J=14.3 \mathrm{~Hz}, 6.8 \mathrm{~Hz}, 1 \mathrm{H}), 2.05-1.85(\mathrm{~m}, 2 \mathrm{H}), 1.67(\mathrm{~d}, J=1.4 \mathrm{~Hz}$, $3 \mathrm{H}), 1.62(\mathrm{~d}, J=1.3 \mathrm{~Hz}, 3 \mathrm{H}), 1.59(\mathrm{~s}, 3 \mathrm{H}), 1.42-1.10(\mathrm{~m}, 5 \mathrm{H})$, Racemate 2: $0.97(\mathrm{~d}, J=6.8 \mathrm{~Hz}, 3 \mathrm{H})$, Racemate 1: $0.94(\mathrm{~d}, J=6.8 \mathrm{~Hz}, 3 \mathrm{H}), 0.86(\mathrm{~d}, J=6.2 \mathrm{~Hz}, 3 \mathrm{H}) ; E$ Isomers $\delta: 5.41$ (td, $J=6.8 \mathrm{~Hz}$, $0.6 \mathrm{~Hz}, 1 \mathrm{H}), 5.13-5.03(\mathrm{~m}, 1 \mathrm{H}), 4.14(\mathrm{~d}, J=6.8 \mathrm{~Hz}, 2 \mathrm{H}), 2.31-2.16(\mathrm{~m}, 1 \mathrm{H}), 2.02-1.88(\mathrm{~m}, 2 \mathrm{H}), 1.67$ $(\mathrm{s}, 3 \mathrm{H}), 1.59(\mathrm{~s}, 3 \mathrm{H}), 1.56(\mathrm{~d}, J=0.6 \mathrm{~Hz}, 3 \mathrm{H}), 1.42-1.10(\mathrm{~m}, 5 \mathrm{H})$, Racemate 3: $0.97(\mathrm{~d}, J=6.8 \mathrm{~Hz}$, 3H), Racemate 4: $0.95(\mathrm{~d}, J=6.8 \mathrm{~Hz}, 3 \mathrm{H}), 0.84(\mathrm{~d}, J=6.2 \mathrm{~Hz}, 3 \mathrm{H}) ;{ }^{13} \mathrm{C}-\mathrm{NMR}\left(63 \mathrm{MHz}, \mathrm{CDCl}_{3}\right)$ Racemate $1(Z) \delta: 144.3(\mathrm{~s}), 131.1(\mathrm{~s}), 124.8(\mathrm{~d}), 123.8(\mathrm{~d}), 58.5(\mathrm{t}), 42.4(\mathrm{t}), 37.0(\mathrm{t}), 31.6(\mathrm{~d}), 30.1(\mathrm{~d})$, 25.6 (q), 25.4 (t), 19.9 (q), 19.2 (q), 18.1 (q), 17.6 (q); Racemate 2 (Z) $\delta: 143.5$ (s), 131.0 (s), 124.8 (d), $124.4(\mathrm{~d}), 58.6(\mathrm{t}), 41.9(\mathrm{t}), 37.8(\mathrm{t}), 31.6(\mathrm{~d}), 30.2(\mathrm{~d}), 25.6(\mathrm{q}), 25.4(\mathrm{t}), 20.1(\mathrm{q}), 19.6(\mathrm{q}), 17.8(\mathrm{q})$, $17.6(\mathrm{q})$; Racemate $3(E) \delta: 143.5(\mathrm{~s}), 131.0(\mathrm{~s}), 124.9(\mathrm{~d}), 123.2(\mathrm{~d}), 59.2(\mathrm{t}), 42.1(\mathrm{t}), 40.0(\mathrm{~d}), 37.5(\mathrm{t})$, 30.0 (d), 25.6 (q), 25.4 (t), 20.2 (q), 19.6 (q), 17.6 (q), 11.9 (q); Racemate 4 (E) $\delta: 144.3$ (s), $131.0(\mathrm{~s})$, 124.9 (d), $123.6(\mathrm{~d}), 59.2(\mathrm{t}), 42.5(\mathrm{t}), 39.8$ (d), 37.0 (t), 29.9 (d), $25.6(\mathrm{q}), 25.3(\mathrm{t}), 19.7$ (q), $19.2(\mathrm{q})$, 17.6 (q), 12.8 (q); MS (70 eV) m/z (\%) Racemate 1 and 2 (Z) $224[\mathrm{M}]^{+}$(2), 69 (100), 82 (77), 109 (65), 81 (55), 41 (55), 95 (44), 55 (44), 67 (40) 98 (39), 43 (33) 123 (20), 135 (11), 151 (10), 191 (6); 
Racemate 3 and 4 (E) $224[\mathrm{M}]^{+}$(4), 69 (100), 82 (71), 109 (61), 81 (60), 41 (50), 55 (40), 95 (39), 67 (37), 43 (33), 83 (24), 71 (19), 123 (16), 151 (15), 191 (6). Anal. Calcd for: $\mathrm{C}_{15} \mathrm{H}_{28} \mathrm{O}$ : C, 80.29; H, 12.58. Found: C, 80.17; H, 12.63.

\subsection{Preparation of Compounds Structurally Related to Farnesyl Acetate (30-35)}

To the stirred and cooled $\left(\mathrm{ca} .0^{\circ} \mathrm{C}\right)$ solution of $6.7 \mathrm{mmol}$ of appropriate compound structurally related to farnesol (24-29) and $0.82 \mathrm{~g}(8 \mathrm{mmol})$ of acetic anhydride, $0.81 \mathrm{~g}(8 \mathrm{mmol})$ of triethylamine was added. After addition, the mixture was stirred for $2 \mathrm{~h}$. Next, $2 \mathrm{~mL}$ of methanol was added and stirring was continued for another $0.5 \mathrm{~h}$. Afterwards, $30 \mathrm{~mL}$ of hexane and $20 \mathrm{~mL}$ of water was added and the hexane layer was separated, washed with brine and dried over anhydrous magnesium sulphate. The obtained acetates were purified by column chromatography on silica with hexane: ethyl acetate (98:2) as the mobile phase. Purity of the products according to GC-MS was $92 \%-99 \%$.

\subsubsection{3,7,8,12-Tetramethyltrideca-2,6,11-trien-1-yl acetate (30)}

Yield 90\%. IR (ATR) 2964, 2923, 2857, 1740, 1666, 1450, 1377, 1230, 1022, $953 \mathrm{~cm}^{-1} .{ }^{1} \mathrm{H}-\mathrm{NMR}$ $\left(250 \mathrm{MHz}, \mathrm{CDCl}_{3}\right)$ Isomer $(2 Z, 6 Z)$ and $(2 Z, 6 E) \delta: 5.40-5.31(\mathrm{~m}, 1 \mathrm{H}), 5.14-5.04(\mathrm{~m}, 2 \mathrm{H}), 4.56(\mathrm{~d}$, $J=7.2 \mathrm{~Hz}, 2 \mathrm{H}), 2.15-2.02(\mathrm{~m}, 5 \mathrm{H}), 2.05(\mathrm{~s}, 3 \mathrm{H}), 1.85(\mathrm{dd}, J=14.7 \mathrm{~Hz}, 7.3 \mathrm{~Hz}, 2 \mathrm{H}), 1.77(\mathrm{~d}, J=1.1 \mathrm{~Hz}$, $3 \mathrm{H}), 1.67(\mathrm{~s}, 3 \mathrm{H}), 1.58(\mathrm{~s}, 3 \mathrm{H}), 1.51(\mathrm{~d}, J=1.0 \mathrm{~Hz}, 3 \mathrm{H}), 1.43-1.18(\mathrm{~m}, 2 \mathrm{H}), 0.95(\mathrm{~d}, J=6.9 \mathrm{~Hz}, 3 \mathrm{H})$; Isomer $(2 E, 6 Z)$ and $(2 E, 6 E) \delta: 5.38-5.30(\mathrm{~m}, 1 \mathrm{H}), 5.13-5.05(\mathrm{~m}, 2 \mathrm{H}), 4.58(\mathrm{~d}, J=7.1 \mathrm{~Hz}, 2 \mathrm{H})$, 2.17-2.00 (m, 5H), 2.05 (s, 3H), $1.85(\mathrm{dd}, J=14.7 \mathrm{~Hz}, 7.1 \mathrm{~Hz}, 3 \mathrm{H}), 1.70$ (s, 3H), 1.67 (s, 3H), 1.58 (s, $3 \mathrm{H}), 1.50(\mathrm{~d}, J=0.8 \mathrm{~Hz}, 3 \mathrm{H}), 1.44-1.16(\mathrm{~m}, 2 \mathrm{H}), 0.95(\mathrm{~d}, J=6.9 \mathrm{~Hz}, 3 \mathrm{H}) ;{ }^{13} \mathrm{C}-\mathrm{NMR}(63 \mathrm{MHz}$, $\mathrm{CDCl}_{3}$ ) Isomer $(2 Z, 6 Z) \delta$ : 170.8 (s), 142.3 (s), 139.6 (s), 131.0 (s), 124.7 (d), 124.1 (d), 119.1 (d), 60.9 $(\mathrm{t}), 34.8(\mathrm{t}), 33.4(\mathrm{~d}), 32.4(\mathrm{t}), 26.1(\mathrm{t}), 25.8(\mathrm{t}), 25.5(\mathrm{q}), 23.4(\mathrm{q}), 20.8(\mathrm{q}), 19.1(\mathrm{q}), 17.8(\mathrm{q}), 17.5(\mathrm{q})$; Isomer $(2 Z, 6 E) \delta: 170.8(\mathrm{~s}), 142.4(\mathrm{~s}), 139.7$ (s), $130.8(\mathrm{~s}), 124.8(\mathrm{~d}), 122.8(\mathrm{~d}), 119.1$ (d), $60.9(\mathrm{t}), 42.3$ $(\mathrm{d}), 35.0(\mathrm{t}), 32.0(\mathrm{t}), 26.3(\mathrm{t}), 26.0(\mathrm{t}), 25.5(\mathrm{q}), 23.3(\mathrm{q}), 20.8(\mathrm{q}), 19.6(\mathrm{q}), 17.5(\mathrm{q}), 12.1(\mathrm{q})$; Isomer $(2 E, 6 Z) \delta: 170.8(\mathrm{~s}), 141.9(\mathrm{~s}), 139.3(\mathrm{~s}), 131.0(\mathrm{~s}), 124.7$ (d), 124.3 (d), 118.2 (d), 61.2 (t), $39.8(\mathrm{t})$, $34.8(\mathrm{t}), 33.4(\mathrm{~d}), 26.1(\mathrm{t}), 25.5(\mathrm{q}), 25.4(\mathrm{t}), 20.8(\mathrm{q}), 19.1(\mathrm{q}), 17.8(\mathrm{q}), 17.5(\mathrm{q}), 16.3(\mathrm{q})$; Isomer $(2 E, 6 E) \delta: 170.8(\mathrm{~s}), 141.9$ (s), 139.3 (s), 130.8 (s), 124.8 (d), 123.1 (d), 118.3 (d), 61.2 (t), 42.2 (d), $39.4(\mathrm{t}), 34.9(\mathrm{t}), 26.0(\mathrm{t}), 25.8(\mathrm{t}), 25.5(\mathrm{q}), 20.8(\mathrm{q}), 19.7(\mathrm{q}), 17.5(\mathrm{q}), 16.2(\mathrm{q}), 12.1(\mathrm{q}) ; \mathrm{MS}(70 \mathrm{eV})$ $\mathrm{m} / \mathrm{z}(\%)$ Isomer (2Z,6Z) $292[\mathrm{M}]^{+}(0), 82$ (100), 69 (56), 109 (32), 95 (27), 41 (24), 55 (24), 67 (24), 81 (24), 43 (21), 83 (20), 121 (15); Isomer (2Z,6E) and (2E,6Z) $292[\mathrm{M}]^{+}(0), 82$ (100), 69 (57), 109 (30), 95 (27), 67 (23), 81 (23), 41 (22), 55 (22), 43 (21), 83 (20), 121 (12); Isomer (2E,6E) $292[\mathrm{M}]^{+}(0), 82$ (100), 69 (52), 109 (29), 95 (26), 43 (23), 67 (22), 81 (21), 41 (19), 55 (18), 83 (17), 121 (11). Anal. Calcd for: $\mathrm{C}_{19} \mathrm{H}_{32} \mathrm{O}_{2}$ : C, 78.03; H, 11.03. Found: C, 77.87; H, 11.08.

3.4.2. (E)-3,8,12-Trimethyltrideca-2,6,11-trien-1-yl acetate (31)

Yield 83\%. IR (ATR) 2963, 2916, 2854, 1740, 1671, 1450, 1376, 1230, 1022, $968 \mathrm{~cm}^{-1}$; ${ }^{1} \mathrm{H}-\mathrm{NMR}$ $\left(250 \mathrm{MHz}, \mathrm{CDCl}_{3}\right)$ Isomer $(2 \mathrm{Z}, 6 \mathrm{E}) \delta: 5.39-5.18(\mathrm{~m}, 3 \mathrm{H}), 5.12-5.02(\mathrm{~m}, 1 \mathrm{H}), 4.54(\mathrm{~d}, J=7.2 \mathrm{~Hz}, 2 \mathrm{H})$, 2.19-1.97 (m, 5H), 1.92 (dd, $J=15.1 \mathrm{~Hz}, 7.3 \mathrm{~Hz}, 2 \mathrm{H}), 1.74$ (d, $J=1.3 \mathrm{~Hz}, 3 \mathrm{H}), 1.66$ (s, 3H), 1.57 (s, $3 \mathrm{H}), 1.25(\mathrm{dd}, J=15.4 \mathrm{~Hz}, 7.3 \mathrm{~Hz}, 2 \mathrm{H}), 0.94$ (d, $J=6.7 \mathrm{~Hz}, 3 \mathrm{H})$; Isomer $(2 E, 6 E) \delta: 5.40-5.18$ (m, 
$3 \mathrm{H}), 5.12-5.03(\mathrm{~m}, 1 \mathrm{H}), 4.56(\mathrm{~d}, J=7.0 \mathrm{~Hz}, 2 \mathrm{H}), 2.18-1.98(\mathrm{~m}, 5 \mathrm{H}), 1.91(\mathrm{dd}, J=15.1 \mathrm{~Hz}, 7.1 \mathrm{~Hz}$, 2H), $1.68(\mathrm{~s}, 3 \mathrm{H}), 1.67(\mathrm{~d}, J=0.9 \mathrm{~Hz}, 3 \mathrm{H}), 1.57$ (s, 3H), 1.25 (dd, $J=15.4 \mathrm{~Hz}, 7.1 \mathrm{~Hz}, 2 \mathrm{H}), 0.93$ (d, $J=6.7 \mathrm{~Hz}, 3 \mathrm{H}) ;{ }^{13} \mathrm{C}-\mathrm{NMR}\left(63 \mathrm{MHz}, \mathrm{CDCl}_{3}\right)$ Isomer $(2 \mathrm{Z}, 6 E) \delta: 169.9$ (s), 141.0 (s), 136.4 (d), 130.2 $(\mathrm{s}), 126.9(\mathrm{~d}), 124.3(\mathrm{~d}), 119.2(\mathrm{~d}), 60.3(\mathrm{t}), 36.7(\mathrm{t}), 35.8(\mathrm{~d}), 31.7(\mathrm{t}), 30.6(\mathrm{t}), 25.3(\mathrm{t}), 25.1(\mathrm{q}), 22.8$ (q), 20.2 (q), 20.1 (q), 17.0 (q); Isomer (2E,6E) $\delta: 169.8$ (s), 140.7 (s), 136.2 (d), 130.1 (s), 127.2 (d), $124.3(\mathrm{~d}), 118.4(\mathrm{~d}), 60.5(\mathrm{t}), 39.1(\mathrm{t}), 36.7(\mathrm{t}), 35.8(\mathrm{~d}), 30.2(\mathrm{t}), 25.3(\mathrm{t}), 25.1(\mathrm{q}), 20.4(\mathrm{q}), 20.1(\mathrm{q})$, 17.0 (q), 15.7 (q); MS (70 eV) m/z (\%) Isomer (2Z,6E) $278[\mathrm{M}]^{+}$(1), 69 (100), 82 (70), 43 (65), 41 (59), 95 (54), 81 (53), 94 (52), 55 (48), 93 (46), 67 (45), 107 (40), 175 (15), 203 (7), 218 (5); Isomer $(2 E, 6 E) 278[\mathrm{M}]^{+}(1), 69$ (100), 43 (83), 82 (66), 41 (62), 95 (56), 81 (53), 67 (44), 94 (43), 55 (42), 93 (41), 107 (40), 150 (20), 203 (10), 218 (4). Anal. Calcd for: $\mathrm{C}_{18} \mathrm{H}_{30} \mathrm{O}_{2}$ : C, 77.65; H, 10.86. Found: C, $77.48 ; \mathrm{H}, 10.97$.

\subsubsection{3,7,8,12-Tetramethyltrideca-2,6-dien-1-yl acetate (32)}

Yield 69\%. IR (ATR) 2956, 2926, 2869, 1741, 1665, 1455, 1378, 1366, 1230, 1022, $954 \mathrm{~cm}^{-1}$; ${ }^{1} \mathrm{H}-\mathrm{NMR}\left(250 \mathrm{MHz}, \mathrm{CDCl}_{3}\right)$ Isomer $(2 Z, 6 Z)$ and $(2 Z, 6 E) \delta: 5.37-5.27(\mathrm{~m}, 1 \mathrm{H}), 5.12-5.01(\mathrm{~m}, 1 \mathrm{H})$, $4.54(\mathrm{~d}, J=7.2 \mathrm{~Hz}, 2 \mathrm{H}), 2.11-1.98(\mathrm{~m}, 5 \mathrm{H}), 2.01(\mathrm{~s}, 3 \mathrm{H}), 1.73(\mathrm{~s}, 3 \mathrm{H}), 1.55-1.40(\mathrm{~m}, 1 \mathrm{H}), 1.47$ (s, $3 \mathrm{H}), 1.32-1.06(\mathrm{~m}, 6 \mathrm{H}), 0.92(\mathrm{~d}, J=6.9 \mathrm{~Hz}, 3 \mathrm{H}), 0.82(\mathrm{~d}, J=6.6 \mathrm{~Hz}, 6 \mathrm{H})$; Isomer $(2 E, 6 Z)$ and $(2 E, 6 E)$ $\delta$ : 5.36-5.27 (m, 1H), 5.10-5.00 (m, 1H), $4.56(\mathrm{~d}, J=7.1 \mathrm{~Hz}, 2 \mathrm{H}), 2.15-1.95(\mathrm{~m}, 5 \mathrm{H}), 2.03(\mathrm{~s}, 3 \mathrm{H})$, $1.68(\mathrm{~s}, 3 \mathrm{H}), 1.56-1.41(\mathrm{~m}, 1 \mathrm{H}), 1.47(\mathrm{~d}, J=1.1 \mathrm{~Hz}, 3 \mathrm{H}), 1.32-1.05(\mathrm{~m}, 6 \mathrm{H}), 0.92(\mathrm{~d}, J=6.6 \mathrm{~Hz}, 3 \mathrm{H})$, $0.83(\mathrm{~d}, J=6.6 \mathrm{~Hz}, 3 \mathrm{H}), 0.82(\mathrm{~d}, J=6.6 \mathrm{~Hz}, 3 \mathrm{H}) ;{ }^{13} \mathrm{C}-\mathrm{NMR}\left(63 \mathrm{MHz}, \mathrm{CDCl}_{3}\right)$ Isomer $(2 Z, 6 Z) \delta$ : $170.9(\mathrm{~s}), 142.4(\mathrm{~s}), 139.9(\mathrm{~s}), 123.9(\mathrm{~d}), 119.2(\mathrm{~d}), 61.0(\mathrm{t}), 39.2(\mathrm{t}), 35.0(\mathrm{t}), 33.9(\mathrm{~d}), 32.5(\mathrm{t}), 27.8(\mathrm{~d})$, $25.9(\mathrm{t}), 25.5(\mathrm{t}), 23.4(\mathrm{q}), 22.6(\mathrm{q}), 22.5(\mathrm{q}), 20.9(\mathrm{q}), 19.3(\mathrm{q}), 17.9(\mathrm{q})$; Isomer $(2 Z, 6 E) \delta$ : $170.9(\mathrm{~s})$, $142.5(\mathrm{~s}), 140.0(\mathrm{~s}), 122.6(\mathrm{~d}), 119.1(\mathrm{~d}), 61.0(\mathrm{t}), 42.6(\mathrm{~d}), 39.1(\mathrm{t}), 35.1(\mathrm{t}), 32.1(\mathrm{t}), 27.9(\mathrm{~d}), 26.3(\mathrm{t})$, $25.3(\mathrm{t}), 23.4(\mathrm{q}), 22.6(\mathrm{q}), 22.5(\mathrm{q}), 20.9$ (q), 19.7 (q), $12.2(\mathrm{q})$; Isomer (2E,6Z) $\delta: 170.9$ (s), $142.1(\mathrm{~s})$, $139.7(\mathrm{~s}), 124.1(\mathrm{~d}), 118.3(\mathrm{~d}), 61.3(\mathrm{t}), 39.9(\mathrm{t}), 39.2(\mathrm{t}), 35.0(\mathrm{t}), 33.9(\mathrm{~d}), 27.9(\mathrm{~d}), 25.5(\mathrm{t}), 25.5(\mathrm{t})$, 22.6 (q), 22.5 (q), 20.9 (q), 19.3 (q), 17.9 (q), 16.3 (q); Isomer (2E,6E) $\delta: 170.9$ (s), 142.1 (s), 139.7 (s), $122.8(\mathrm{~d}), 118.3(\mathrm{~d}), 61.3(\mathrm{t}), 42.6(\mathrm{~d}), 39.5(\mathrm{t}), 39.1(\mathrm{t}), 35.1(\mathrm{t}), 27.9(\mathrm{~d}), 25.9(\mathrm{t}), 25.3(\mathrm{t}), 22.6(\mathrm{q})$, 22.5 (q), 20.9 (q), 19.7 (q), 16.3 (q), 12.2 (q); MS (70 eV) m/z (\%) Isomer (2Z,6Z) $294[\mathrm{M}]^{+}$(0), 69 (100), 55 (64), 80 (53), 93 (52), 43 (51), 121 (43), 111 (34), 83 (33), 97 (32), 149 (13), 234 (8), 166 (7); Isomer (2Z,6E) and (2E,6Z) $294[\mathrm{M}]^{+}(0), 69$ (100), 55 (63), 43 (49), 93 (44), 80 (44), 111 (42), 121 (35), 97 (35), 83 (34), 57 (33), 149 (15), 166 (9), 234 (8); Isomer (2E,6E) $294[\mathrm{M}]^{+}(0), 69$ (100), 55 (61), 43 (52), 111 (46), 93 (34), 83 (33), 97 (32), 57 (32), 121 (24), 149 (14), 166 (14), 234 (6). Anal. Calcd for: $\mathrm{C}_{19} \mathrm{H}_{34} \mathrm{O}_{2}$ : C, 77.50; H, 11.64. Found: C, 77.38; H, 11.73.

3.4.4. 3,5,9-Trimethyldeca-2,8-dien-1-yl acetate (33)

Yield 82\%. IR (ATR) 2966, 2916, 2849, 1740, 1668, 1453, 1378, 1229, 1022, $953 \mathrm{~cm}^{-1}$; ${ }^{1} \mathrm{H}-\mathrm{NMR}$ $\left(700 \mathrm{MHz}, \mathrm{CDCl}_{3}\right)$ Isomer $Z: \delta: 5.41(\mathrm{t}, J=7.1 \mathrm{~Hz}, 1 \mathrm{H}), 5.10-5.06(\mathrm{~m}, 1 \mathrm{H}), 4.56(\mathrm{~d}, J=7.1 \mathrm{~Hz}, 2 \mathrm{H})$, 2.06-2.00 (m, 2H), $2.04(\mathrm{~s}, 3 \mathrm{H}), 1.95(\mathrm{dd}, J=13.3 \mathrm{~Hz}, 8.5 \mathrm{~Hz}, 2 \mathrm{H}), 1.73$ (s, 3H), 1.68 (s, 3H), 1.63 $(\mathrm{dd}, J=13.3 \mathrm{~Hz}, 6.5 \mathrm{~Hz}, 1 \mathrm{H}), 1.60(\mathrm{~s}, 3 \mathrm{H}), 1.34-1.28(\mathrm{~m}, 1 \mathrm{H}), 1.16-1.09$ (m, 2H), $0.83(\mathrm{~d}, J=6.5 \mathrm{~Hz}$, $3 \mathrm{H})$; Isomer $E$ : $\delta$ : $5.33-5.30(\mathrm{~m}, 1 \mathrm{H}), 5.10-5.06(\mathrm{~m}, 1 \mathrm{H}), 4.59(\mathrm{~d}, J=7.1 \mathrm{~Hz}, 2 \mathrm{H}), 2.05(\mathrm{~s}, 3 \mathrm{H}), 2.01$ (dd, $J=15.4 \mathrm{~Hz}, 7.1 \mathrm{~Hz}, 2 \mathrm{H}), 1.95(\mathrm{dd}, J=13.3 \mathrm{~Hz}, 8.4 \mathrm{~Hz}, 1 \mathrm{H}), 1.80$ (dd, $J=13.3 \mathrm{~Hz}, 8.4 \mathrm{~Hz}, 1 \mathrm{H})$, 
$1.68(\mathrm{~s}, 3 \mathrm{H}), 1.66(\mathrm{~s}, 3 \mathrm{H}), 1.63(\mathrm{dd}, J=13.3 \mathrm{~Hz}, 6.6 \mathrm{~Hz}, 1 \mathrm{H}), 1.60(\mathrm{~s}, 3 \mathrm{H}), 1.34-1.28(\mathrm{~m}, 1 \mathrm{H})$, 1.15-1.08 (m, 2H), $0.82(\mathrm{~d}, J=6.6 \mathrm{~Hz}, 3 \mathrm{H}) ;{ }^{13} \mathrm{C}-\mathrm{NMR}\left(176 \mathrm{MHz}, \mathrm{CDCl}_{3}\right)$ Isomer $Z: \delta: 171.0(\mathrm{~s})$, $141.7(\mathrm{~s}), 131.1(\mathrm{~s}), 124.6(\mathrm{~d}), 120.0(\mathrm{~d}), 61.1(\mathrm{t}), 39.5(\mathrm{t}), 36.9(\mathrm{t}), 30.8(\mathrm{~d}), 25.6(\mathrm{q}), 25.6(\mathrm{t}), 23.6(\mathrm{q})$, 20.9 (q), 19.2 (q), 17.6 (q); Isomer $E: \delta: 171.0$ (s), 141.2 (s), 131.1 (s), 124.7 (d), 119.7 (d), $61.3(\mathrm{t})$, $47.5(\mathrm{t}), 36.8(\mathrm{t}), 30.1(\mathrm{~d}), 25.6(\mathrm{q}), 25.4(\mathrm{t}), 20.9(\mathrm{q}), 19.3(\mathrm{q}), 17.5(\mathrm{q}), 16.1(\mathrm{q}) ; \mathrm{MS}(70 \mathrm{eV}) \mathrm{m} / \mathrm{z}(\%)$ Isomer Z: $238[\mathrm{M}]^{+}$(1), 69 (100), 95 (84), 109 (78), 107 (69), 43 (58), 41 (54), 82 (43), 55 (43), 67 (42), 163 (41), 93 (40), 81 (38), 122 (25), 135 (23), 178 (16); Isomer E: 238 [M] (1), 69 (100), 95 (81), 109 (71), 107 (66), 43 (60), 41 (50), 82 (46), 67 (42), 55 (39), 163 (38), 93 (38), 81 (33), 122 (22), 135 (20), 178 (16). Anal. Calcd for: $\mathrm{C}_{15} \mathrm{H}_{26} \mathrm{O}_{2}$ : C, 75.58; H, 10.99. Found: C, 75.77; H, 10.83.

\subsubsection{3,6,10-Trimethylundeca-2,9-dien-1-yl acetate (34)}

Yield 86\%. IR (ATR) 2965, 2916, 2856, 1740, 1671, 1453, 1378, 1229, 1122, $853 \mathrm{~cm}^{-1}$; ${ }^{1} \mathrm{H}-\mathrm{NMR}$ $\left(700 \mathrm{MHz}, \mathrm{CDCl}_{3}\right)$ Isomer $Z: \delta: 5.34-5.31(\mathrm{~m}, 1 \mathrm{H}), 5.11-5.08(\mathrm{~m}, 1 \mathrm{H}), 4.56(\mathrm{~d}, J=7.1 \mathrm{~Hz}, 1 \mathrm{H})$, 2.10-2.02 (m, 2H), $2.05(\mathrm{~s}, 3 \mathrm{H}), 2.02-1.97(\mathrm{~m}, 1 \mathrm{H}), 1.97-1.91(\mathrm{~m}, 1 \mathrm{H}), 1.75(\mathrm{~s}, 3 \mathrm{H}), 1.68(\mathrm{~s}, 3 \mathrm{H}), 1.60$ $(\mathrm{s}, 3 \mathrm{H}), 1.46-1.36(\mathrm{~m}, 2 \mathrm{H}), 1.35-1.30(\mathrm{~m}, 1 \mathrm{H}), 1.26-1.18(\mathrm{~m}, 1 \mathrm{H}), 1.18-1.12(\mathrm{~m}, 1 \mathrm{H}), 0.90(\mathrm{~d}$, $J=6.5 \mathrm{~Hz}, 3 \mathrm{H})$; Isomer $E: \delta: 5.36-5.31(\mathrm{~m}, 1 \mathrm{H}), 5.11-5.08(\mathrm{~m}, 1 \mathrm{H}), 4.58(\mathrm{~d}, J=7.1 \mathrm{~Hz}, 1 \mathrm{H})$, 2.09-2.03 (m, 1H), $2.05(\mathrm{~s}, 3 \mathrm{H}), 2.02-1.97(\mathrm{~m}, 2 \mathrm{H}), 1.96-1.90(\mathrm{~m}, 1 \mathrm{H}), 1.69(\mathrm{~s}, 3 \mathrm{H}), 1.68(\mathrm{~s}, 3 \mathrm{H}), 1.60$ (s, 3H), $1.46-1.41(\mathrm{~m}, 1 \mathrm{H}), 1.39(\mathrm{dd}, J=12.6,6.5 \mathrm{~Hz}, 1 \mathrm{H}), 1.36-1.30(\mathrm{~m}, 1 \mathrm{H}), 1.26-1.20(\mathrm{~m}, 1 \mathrm{H})$, $1.18-1.12(\mathrm{~m}, 1 \mathrm{H}), 0.88(\mathrm{~d}, J=6.5 \mathrm{~Hz}, 3 \mathrm{H}) ;{ }^{13} \mathrm{C}-\mathrm{NMR}\left(176 \mathrm{MHz}, \mathrm{CDCl}_{3}\right)$ Isomer $Z: \delta: 170.9(\mathrm{~s})$, $143.4(\mathrm{~s}), 131.0(\mathrm{~s}), 124.7(\mathrm{~d}), 118.5(\mathrm{~d}), 60.9(\mathrm{t}), 36.9(\mathrm{t}), 35.4(\mathrm{t}), 32.4(\mathrm{~d}), 29.6(\mathrm{t}), 25.6(\mathrm{q}), 25.4(\mathrm{t})$, 23.4 (q), 20.9 (q), 19.4 (q), 17.5 (q); Isomer $E$ : $\delta: 170.9$ (s), 142.8 (s), 130.9 (s), 124.8 (d), 117.9 (d), $61.3(\mathrm{t}), 37.0(\mathrm{t}), 36.9(\mathrm{t}), 34.8(\mathrm{t}), 32.1(\mathrm{~d}), 25.6(\mathrm{q}), 25.4(\mathrm{t}), 20.9(\mathrm{q}), 19.4(\mathrm{q}), 17.5(\mathrm{q}), 16.3(\mathrm{q}) ; \mathrm{MS}$ $(70 \mathrm{eV}) \mathrm{m} / z$ (\%) Isomer Z: $252[\mathrm{M}]^{+}$(1), 69 (100), 81 (72), 109 (68), 107 (60), 41 (52), 43 (51), 82 (50), 67 (39), 55 (36), 93 (31), 121 (28), 136 (25), 177 (23), 149 (20); Isomer E: 252 [M] (2), 69 (100), 81 (77), 109 (67), 43 (56), 107 (54), 41 (51), 82 (45), 67 (36), 55 (34), 93 (28), 121 (26), 136 (20), 149 (19), 177 (18). Anal. Calcd for: $\mathrm{C}_{16} \mathrm{H}_{28} \mathrm{O}_{2}$ : C, 76.14; H, 11.18. Found: C, 76.31; H, 11.23.

\subsubsection{3,4,6,10-Tetramethylundec-2,9-dien-1-yl acetate (35)}

Yield 91\%. IR (ATR) 2956, 2915, 2869, 1741, 1665, 1455, 1375, 1230, 1022, $953 \mathrm{~cm}^{-1}$; ${ }^{1} \mathrm{H}-\mathrm{NMR}$ $\left(250 \mathrm{MHz}, \mathrm{CDCl}_{3}\right)$ Racemate 1 and $2(\mathrm{Z}) \delta: 5.34-5.25(\mathrm{~m}, 1 \mathrm{H}), 5.12-5.02(\mathrm{~m}, 1 \mathrm{H}), 4.62-4.54(\mathrm{~m}, 2 \mathrm{H})$, 2.83-2.71 (m, 1H), $2.03(\mathrm{~s}, 3 \mathrm{H}), 2.00-1.86(\mathrm{~m}, 2 \mathrm{H}), 1.67(\mathrm{~s}, 3 \mathrm{H}), 1.64(\mathrm{~d}, J=1.4 \mathrm{~Hz}, 3 \mathrm{H}), 1.59$ (s, $3 \mathrm{H}), 1.47-1.06(\mathrm{~m}, 5 \mathrm{H})$, Racemate 2: $0.96(\mathrm{~d}, J=6.9 \mathrm{~Hz}, 3 \mathrm{H})$, Racemate 1: $0.94(\mathrm{~d}, J=6.9 \mathrm{~Hz}, 3 \mathrm{H})$, $0.85(\mathrm{t}, J=6.4 \mathrm{~Hz}, 3 \mathrm{H})$; Racemate 3 and $4(E) \delta: 5.34(\mathrm{t}, J=6.9 \mathrm{~Hz}, 1 \mathrm{H}), 5.12-5.02(\mathrm{~m}, 1 \mathrm{H}), 4.58(\mathrm{~d}$, $J=6.9 \mathrm{~Hz}, 2 \mathrm{H}), 2.33-2.18(\mathrm{~m}, 1 \mathrm{H}), 2.04(\mathrm{~s}, 3 \mathrm{H}), 2.00-1.86(\mathrm{~m}, 2 \mathrm{H}), 1.67(\mathrm{~s}, 3 \mathrm{H}), 1.61(\mathrm{~d}, J=0.6 \mathrm{~Hz}$, $3 \mathrm{H}), 1.59(\mathrm{~s}, 3 \mathrm{H}), 1.47-1.06(\mathrm{~m}, 5 \mathrm{H})$, Racemate 3: $0.97(\mathrm{~d}, J=6.9 \mathrm{~Hz}, 3 \mathrm{H}), 0.84(\mathrm{~d}, J=6.3 \mathrm{~Hz}, 3 \mathrm{H}$ Racemate 4: $0.96(\mathrm{~d}, J=6.9 \mathrm{~Hz}, 3 \mathrm{H}), 0.84(\mathrm{~d}, J=6.9 \mathrm{~Hz}, 3 \mathrm{H}) ;{ }^{13} \mathrm{C}-\mathrm{NMR}\left(63 \mathrm{MHz}, \mathrm{CDCl}_{3}\right)$ Racemate 1 and 2: $170.9(\mathrm{~s}), 147.0(\mathrm{~s}), 146.3(\mathrm{~s}), 130.8(\mathrm{~s}), 124.8(\mathrm{~d}), 119.0(\mathrm{~d}), 118.5(\mathrm{~d}), 60.4(\mathrm{t}), 42.2(\mathrm{t}), 41.8$ $(\mathrm{t}), 37.7(\mathrm{t}), 31.7$ (d), $30.1(\mathrm{~d}), 30.0(\mathrm{~d}), 25.6(\mathrm{q}), 25.3(\mathrm{t}), 20.9(\mathrm{q}), 19.9(\mathrm{q}), 19.8(\mathrm{q}), 19.6(\mathrm{q}), 18.9(\mathrm{q})$, 18.1 (q), 17.8 (q), 17.5 (q); Racemate 3: 170.8 (s), 145.7 (s), 130.8 (s), 124.8 (d), 118.0 (d), $61.2(\mathrm{t})$, $42.0(\mathrm{t}), 40.0(\mathrm{~d}), 37.4(\mathrm{t}), 30.0(\mathrm{~d}), 25.6(\mathrm{q}), 25.3(\mathrm{t}), 20.9(\mathrm{q}), 20.0(\mathrm{q}), 19.5(\mathrm{q}), 17.5(\mathrm{q}), 12.1(\mathrm{q}) ;$ Racemate 4: 170.9 (s), 146.6 (s), 130.8 (s), 124.8 (d), 117.5 (d), 61.3 (t), 42.4 (t), 39.8 (d), 37.0 (t), 
29.9 (d), 25.6 (q), 25.3 (t), 20.9 (q), 19.7 (q), 19.1 (q), 17.5 (q), 12.8 (q); MS (70 eV) m/z (\%) Racemate 1 and 2 (Z) $266[\mathrm{M}]^{+}$(1), 82 (100), 69 (76), 43 (57), 109 (55), 81 (52), 95 (44), 67 (38), 41 (37), 55 (32), 107 (28), 121 (26), 123 (25), 135 (15), 191 (12), 206 (6); Racemate $3(E) 266[\mathrm{M}]^{+}$(2), 82 (100), 69 (94), 43 (71), 109 (65), 81 (54), 95 (53), 41 (47), 67 (40), 121 (36), 55 (33), 107 (31), 123 (27), 135 (20), 191 (12), 206 (7); Racemate 4 (E) 266 [M] (1), 69 (100), 82 (97), 43 (71), 81 (67), 109 (65), 95 (53), 41 (47), 67 (40), 121 (38), 55 (34), 107 (30), 123 (26), 135 (19), 191 (11), 206 (6). Anal. Calcd for: $\mathrm{C}_{17} \mathrm{H}_{30} \mathrm{O}_{2}$ : C, 76.41; H, 11.35. Found: C, 76.49; H, 11.28.

\section{Conclusions}

The compounds described in this paper are potentially useful in fragrance compositions as antimicrobial agents and showed better or comparable activity to parent terpenoids. Their negligible toxicity to the tested human cell lines may indicate possible safe use. The generated pharmacophore models indicate significant steric factors which determine the antimicrobial activity of the compounds described here and probably of other structurally similar compounds.

\section{Acknowledgements}

This work was supported by a research grant from the National Science Centre Poland (N N209 410739). The authors wish to thank Wieslaw Wasilewski for the NMR analyses. The authors are grateful to the Reviewer for helpful suggestions regarding the pharmacophore modelling.

\section{Author Contributions}

R.B. and P.Ś. synthesised and purified the compounds. M.S. performed the antimicrobial experiments, M.Z.-S. performed the cytotoxicity experiments. All authors analysed the results. R.B. prepared the manuscript. The concept of the work belongs to R.B. All of the authors contributed to the paper and approved the manuscript.

\section{Conflicts of Interest}

The authors declare no conflict of interest.

\section{References}

1. Katsuyama, M.; Kobayashi, Y.; Ichikawa, H.; Mizuno, A.; Miyachi, Y.; Matsunaga, K.; Kawashima, M. A novel method to control the balance of skin microflora Part 2. A study to assess the effect of a cream containing farnesol and xylitol on atopic dry skin. J. Dermatol. Sci. 2005, 38, 207-213.

2. Togashi, N.; Inoue, Y.; Hamashima, H.; Takano, A. Effects of two terpene alcohols on the antibacterial activity and the mode of action of farnesol against Staphylococcus aureus. Molecules 2008, 13, 3069-3076.

3. Jabra-Rizk, M.A.; Meiller, T.F.; James, C.E.; Shirtlif, M.E. Effect of farnesol on Staphylococcus aureus biofilm formation and antimicrobial susceptibility. Antimicrob. Agents Chemother. 2006, 50, 1463-1469. 
4. Brilhante, R.S.; Valente, L.G.; Rocha, M.F.; Bandeira, T.J.P.G.; Cordeiro, R.A.; Lima, R.A.C.; Leite, J.J.G.; Ribeiro, J.F.; Pereira, J.F.; Castelo-Branco, D.S.C.M.; et al. Sesquiterpene farnesol contributes to increased susceptibility to $\beta$-lactams in strains of Burkholderia pseudomallei. Antimicrob. Agents Chemother. 2012, 56, 2198-2200.

5. Cordeiro, R.A.; Teixeira, C.E.; Brilhante, R.S.; Castelo-Branco, D.S.; Paiva, M.A.; Giffoni Leite, J.J.; Lima, D.T.; Monteiro, A.J.; Sidrim, J.J.; Rocha, M.F. Minimum inhibitory concentrations of amphotericin B, azoles and caspofungin against Candida species are reduced by farnesol. Med. Mycol. 2013, 51, 53-59.

6. Tao, R.; Wang, Ch.Z.; Kong, Z.W. Antibacterial/antifungal activity and synergistic Interactions between polyprenols and other lipids isolated from Ginkgo Biloba L. leaves. Molecules 2013, 18, 2166-2182.

7. Brehm-Stecher, B.F.; Johnson, E.A. Sensitization of Staphylococcus aureus and Escherichia coli to antibiotics by the sesquiterpenoids nerolidol, farnesol, bisabolol, and apritone. Antimicrob. Agents Chemother. 2003, 47, 3357-3360.

8. Nagaki, M.; Narita, T.; Ichikawa, H.; Kawakami, J.; Nakane, A. Antibacterial and antifungal activities of isoprenoids. Trans. Mater. Sci. Jpn. 2011, 36, 55-58.

9. Shin, K.H.; Chi, H.J.; Lim, S.S.; Cho, S.H.; Moon, H.I.; Yu, J.H. Antimicrobial activities of volatile essential oils from Korean aromatic plants. Nat. Prod. Sci. 1997, 3, 141-147.

10. Lamikanra, O.; Richard, O.A.; Parker, A. Ultraviolet induced stress response in fresh cut cantaloupe. Phytochemistry 2002, 60, 27-32.

11. Tatman, D.; Mo, H. Volatile isoprenoid constituents of fruits, vegetables and herbs cumulatively suppress the proliferation of murine B16 melanoma and human HL-60 leukemia cells. Cancer Lett. 2002, 175, 129-139.

12. Da Silv Pinto, A.C.; Silva, L.F.R.; Cavalcanti, B.C.; Melo, M.R.S.; Chaves, F.C.M.; Lotufo, L.V.C.; de Moraes, M.O.; de Andrade-Neto, V.F.; Tadei, W.P.; Pessoa, C.O.; et al. New antimalarial and cytotoxic 4-nerolidylcatechol derivatives. Eur. J. Med. Chem. 2009, 44, 2731-2735.

13. Joo, J.H.; Jetten, A.M. Molecular mechanisms involved in farnesol-induced apoptosis. Cancer Lett. 2009, 287, 123-135.

14. Wang, Z.; Chen, H.T.; Roa, W.; Finlay, W.H. Farnesol for aerosol inhalation: Nebulization and activity against human lung cancer cells. J. Pharm. Pharm. Sci. 2003, 6, 95-100.

15. Bonikowski, R.; Sikora, M.; Kula, J.; Kunicka, A. Thienyl analogues of acyclic monoterpene alcohols and their biological activity. J. Sci. Food Agric. 2009, 89, 2088-2095.

16. Kula, J.; Sikora, M.; Hammad, D.; Bonikowski, R.; Balawejder, M.; Nowicki, J. Synthesis of furyl analogues of acyclic monoterpenes. Flavour Frag. J. 2005, 20, 487-491.

17. Bonikowski, R.; Świtakowska, P.; Jabłońska, A.; Kula, J.; Sienkiewicz, M.; Gabrysiak, J.; Kajrukszto, K. Characteristics of some synthetic terpenoids with a grapefruit odour discovered by serendipity. Flavour Frag. J. 2014, 29, 380-387.

18. Bonikowski, R.; Świtakowska, P.; Kula, J. Synthesis, odour evaluation and antimicrobial activity of some geranyl acetone and nerolidol analogues. Flavour Frag. J. 2015, 30, 238-244.

19. Thormar, H. Lipids and Essential Oils as Antimicrobial Agents; John Wiley \& Sons, Ltd.: Chichester, UK, 2010; pp. 211-223. 
20. Stoffels, K.M. Modern and safe antimicrobial stabilization of cosmetic products. $H \& P C$ Today 2012, 7, 18-21.

21. Chuzel, O.; Piva, O. Tandem Michael-Wittig-Horner reaction: Application to the synthesis of bisabolanes. Synth. Commun. 2003, 33, 393-402.

22. Jin, J.; Zhang, J.Y.; Guo, N.; Sheng, H.; Li, L.; Liang, J.C.; Wang, X.L.; Li, Y.; Liu, M.Y.; $\mathrm{Wu}$, X.P.; et al. Farnesol, a potential efflux pump inhibitor in Mycobacterium smegmatis. Molecules 2010, 15, 7750-7762.

23. Carson, C.F.; Hammer, K.A.; Riley, T.V. Broth micro-dilution method for determining the susceptibility of Escherichia coli and Staphylococcus aureus to the essential oil of Melaleuca alternifolia (tea tree oil). Microbios 1995, 82, 181-185.

Sample Availability: Samples of the compounds 6-35 are available from the authors.

(C) 2015 by the authors; licensee MDPI, Basel, Switzerland. This article is an open access article distributed under the terms and conditions of the Creative Commons Attribution license (http://creativecommons.org/licenses/by/4.0/). 